Columbia Law School

Scholarship Archive

1992

\title{
No "Sweat"? Copyright and Other Protection of Works of Information after Feist v. Rural Telephone
}

Jane C. Ginsburg

Columbia Law School, jane.ginsburg@law.columbia.edu

Follow this and additional works at: https://scholarship.law.columbia.edu/faculty_scholarship

Part of the Intellectual Property Law Commons, and the Supreme Court of the United States Commons

\section{Recommended Citation}

Jane C. Ginsburg, No "Sweat"? Copyright and Other Protection of Works of Information after Feist v. Rural Telephone, 92 CoLUM. L. REV 338 (1992).

Available at: https://scholarship.law.columbia.edu/faculty_scholarship/60

This Article is brought to you for free and open access by the Faculty Publications at Scholarship Archive. It has been accepted for inclusion in Faculty Scholarship by an authorized administrator of Scholarship Archive. For more information, please contact scholarshiparchive@law.columbia.edu. 


\title{
NO "SWEAT"? COPYRIGHT AND OTHER PROTECTION OF WORKS OF INFORMATION AFTER FEIST $V$. RURAL TELEPHONE
}

\author{
Jane C. Ginsburg* \\ TABLE OF CONTENTS
}

Introduction

I. Federal Copyright Protection of Information Compilations 342

A. Originality in Fact Compilations After Feist ........ 343

B. Scope of Protection of Original Compilations ........ 348

II. State Law Anticopying Protection and Its Federal

Preemption ................................ 353

A. State Common-Law Claims Against Misappropriation

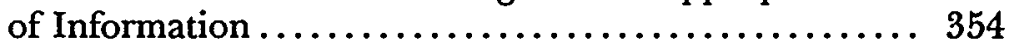

B. Preemption Under Section 301 of the 1976 Copyright Act ..................................... 355

C. Congressional Occupation of the Field Under the Copyright Act and Under the Patent-Copyright Clause 361

D. Commerce Clause and Sister-State Preemption .......

III. Congress' Constitutional Authority to Enact a Statute Protecting Against Misappropriation of Compiled Information

A. Patent-Copyright Clause Limitations on Congress' Authority to Legislate Under the Commerce Clause ... 369

B. Congress' Authority to Implement the Terms of the Patent-Copyright Clause ....................... 374

C. First Amendment Implications of a Statute Protecting Compiled Information ....................... 384

Conclusion

* Professor of Law, Columbia University School of Law. Copyright 1992, Jane C. Ginsburg. Thanks to Douglas Baird, Richard Briffault, Hal Edgar, Martin Ginsburg, Michael Klipper, James Liebman, Jessica Litman, Henry Monaghan, Gerald Neuman, Pamela Samuelson, George Spera, and Jon Weinberg. Judith Church and Susan Sabreen, both Columbia Law School class of 1992, provided very helpful research assistance. The participants in the Columbia Law School Faculty Symposium offered many valuable suggestions on an earlier draft. 
The Congress shall have Power ... [t]o promote the Progress of Science and useful Arts, by securing for limited Times to Authors and Inventors the exclusive Right to their respective Writings and Discoveries ${ }^{1}$

Copyright protection subsists, in accordance with this title, in original works of authorship fixed in any tangible medium of expression, now known or later developed ....2

\section{INTRODUCTION}

The Supreme Court's unanimous decision last Term in Feist Publications, Inc. v. Rural Telephone Service Co. ${ }^{3}$ proscribed copyright protection for works of information that fail to manifest a modicum of creative originality in selection or arrangement. Discarding a long-if lately uneasy-tradition of U.S. copyright coverage of informational works that display far greater industriousness than imagination, the Court ruled that copyright does not secure the "sweat of the brow" or the investment of resources in the compilation of a work of information. The Court thus stripped away or sharply reduced the copyright protection afforded a variety of "information products," from directories and mailing lists to computerized databases.

The Court not only grounded its decision in the text of the copyright statute, but declared-and several times reiterated-that a threshold of creative originality was "constitutionally mandated." 4 The frequent invocations of the Constitution are not merely rhetorical flourishes; they implement a policy favoring general, free access to disclosed data. ${ }^{5}$ If these invocations reduce debate regarding the availability and the scope of copyright protection for works of information, they augment the uncertainties concerning both the availability of statelaw protection and the authority of Congress to enact other forms of federal anticopying protection for these kinds of works. The Feist Court's sweeping declarations of constitutional limitations on Congress' copyright power put in issue the respective roles of the Court and Congress in defining not only the contours and key terms of copy-

1. U.S. Const. art. I, $\S 8, \mathrm{cl} .8$.

2. 17 U.S.C. $\S$ I02(a) (1988).

3. 111 S. Ct. 1282 (1991). Justice Blackmun concurred in the result.

4. See, e.g., id. at 1288 (quoting L. Ray Patterson \& Craig Joyce, Monopolizing the Law: The Scope of Copyright Protection for Law Reports and Statutory Compilations, 36 UCLA L. Rev. 719, 763, n.155 (1989)); see also Paul Goldstein, Copyright, 38 J. Copyright Soc'y 109, 119 (1991) (Justice O'Connor's opinion declares a constitutional originality standard "no fewer than thirteen times").

5. See, e.g., Marci A. Hamilton, Justice O'Connor's Opinion in Feist Publications, lnc. v. Rural Tel. Serv. Co.: An Uncommon Though Characteristic Approach, 38 J. Copyright Soc'y 83, 87-90 (1991); cf. Pamela Samuelson, Information as Property: Do Ruckelshaus and Carpenter Signal a Changing Direction in Intellectual Property Law?, 38 Cath. U. L. Rev. 365, 395-400 (1989) (discussing Supreme Court's protection of undisclosed information). 
right law, but also the scope of Congress' authority to provide for intellectual property protection under other constitutional sources of legislative power.

In an article published in this Review shortly before the Feist decision, I argued that courts should recognize that U.S. law had evolved two different kinds of copyright protection, for "high authorship" and "low authorship" works respectively. 6 The latter kinds of works, such as directories, maps, computer databases, and similar information compilations, may manifest little, if any, creative originality, but are highly useful endeavors. Since the first copyright statute in I790, Congress had sought to encourage production of these kinds of works. In high authorship works, such as novels, paintings, and musical compositions, an authorial personality permeates the work; the creation emanates from the subjective choices made by the author in her elaboration of the work. The object of protection in low authorship works is necessarily different from that of high authorship creations. A high authorship work represents not only economic interests, but the persona of its creator(s), and exploitation of the copyright in these kinds of works therefore implicates both the spirit and the flesh. ${ }^{7}$ By contrast, copyright in low authorship works essentially secures the labor and resources-or "sweat"-invested in the work. Assertions that the copyright covers the compiler's personal selection and arrangement of data are often largely pretextual.

In my earlier article, I contended that the problem was not the protection, but the pretext. ${ }^{8}$ Copyright law could and should, I then maintained, cover low authorship works, but it should do so on low authorship terms-that is, with a scope of protection limited by a form of collective licensing. 9 Since a de facto dual copyright system already existed, there was no need to achieve doctrinal purity either by eliminating low authorship copyright, or by disguising low authorship works as high authorship endeavors. Rather, it was necessary to recognize and organize our dual system in a manner that would continue to sup-

6. See Jane C. Ginsburg, Creation and Commercial Value: Copyright Protection of Works of lnformation, 90 Colum. L. Rev. 1865, 1873-93 (1990) [hereinafter Creation and Commercial Value].

7. Article 6bis of the Berne Convention for the Protection of Literary and Artistic Works, to which the United States adhered in March 1989, expresses the dual nature of copyright. 1t states that an author's interests in receiving attribution for her work and in preserving the work's integrity exist "[i]ndependently of the author's economic rights." Berne Convention for the Protection of Literary and Artistic Works (Paris Text), July 24, 1971 , art. 6bis(1) [hereinafter Berne Convention], reprinted in 4 Melville B. Nimmer \& David Nimmer, Nimmer on Copyright app. 27 (1991) [hereinafter Nimmer on Copyright]. For further discussion of American protection of an author's personal interests in her work, see, e.g., Jane C. Ginsburg \& John M. Kernochan, One Hundred and Two Years Later: The U.S. Joins the Berne Convention, 13 Colum.-VLA J.L. \& Arts 1, 27-37 (1988), and works cited therein.

8. See Creation and Commercial Value, supra note 6, at 1870.

9. See id. at 1924-36. 
ply incentives for the creation of both kinds of works. ${ }^{10}$

In Feist, the Supreme Court took the high authorship ground and ruled out "sweat"-based copyright protection for works of information. ${ }^{11}$ The Court elected to impose a unitary concept of creative originality and declared that the Constitution compels this standard. ${ }^{12}$ But does the creative originality standard allow room for protection of compilations, particularly electronic databases? If not, has the Court's insistence on a constitutional standard foreclosed Congress from acting meaningfully in this field? The Constitution empowers Congress to grant copyright to encourage the production of works; the incentive supplies a means to advance knowledge. ${ }^{13}$ But the Feist Court concluded that the Constitution does not permit extension of the copyright incentive to uncreative, albeit informative, works. If these works nonetheless require a prompt to their production, then evaluation of Congress' remaining power to regulate the creation and exploitation of information products such as directories and databases is pressing.

Part I of this Article addresses the copyrightability of and scope of protection for works of information after Feist. Part II considers statelaw protections and their federal preemption. Potential sources of preemption include the federal Copyright Act, the Patent-Copyright Clause, the Commerce Clause, and considerations of horizontal (or sister-state) federalism. Part 111 inquires into Congress' constitutional authority to enact a statute protecting compiled information under the Commerce Clause or the Patent-Copyright Clause, and assesses the conflicts such a statute might present with the First Amendment.

While Feist may properly have interpreted the text of the 1976 Copyright Act, the opinion's repeated invocation of constitutional constraints on copyright protection of information erects unnecessary if not insuperable barriers to alternative sources of protection for information compilations. State law protection may well be preempted, and at any rate is not desirable in an interstate information market. Federal law protection under a revised copyright statute, or under a Commerce Clause-based misappropriation statute, may prove difficult to reconcile with Feist's constitutionally derived endorsement of free-riding on previously gathered information. However, Feist neglects another, at least equally important, constitutional goal: to provide incentives to the creation of works so that knowledge will progress. Consideration of this policy leads me to conclude that Congress does retain the authority to award a carefully tailored property right to information compilers.

10. See id. at 1907-16.

11. See Feist Publications, lnc. v. Rural Tel. Serv. Co., 111 S. Ct. 1282, 1295 (1991).

12. See id. at 1296.

13. See U.S. Const. art. $1, \S 8, \mathrm{cl} .8$. 


\section{Federal Copyright Protection of Information Compilations}

The Court's decision in Feist Publications, Inc. v. Rural Telephone Service Co. ${ }^{14}$ addressed the copyrightability of a white pages telephone directory. Plaintiff had received the local telephone service franchise for certain towns in Kansas, and as part of its obligations in providing local telephone service, plaintiff published a directory alphabetically listing all telephone subscribers in those towns. ${ }^{15}$ Defendant published telephone directories covering an overlapping, but not identical, geographic territory. When plaintiff refused permission to defendant to reproduce plaintiff's listings in defendant's somewhat different directory, defendant nonetheless used plaintiff's directory as a source of information from which it gathered directory listings for its compilation. ${ }^{16}$ The lower courts found copyright infringement, largely relying on abundant prior caselaw protecting telephone directories from being copied, even when the copier's work did not directly compete with the original. ${ }^{17}$ The Supreme Court granted certiorari to determine the proper scope of copyright protection, ${ }^{18}$ but ultimately reversed on the ground that plaintiff's white pages directory was not copyrightable at all.

Before Feist, many courts had concluded that however banal the constitutive elements of an information compilation, the assemblage of the whole somehow assumed the requisite originality, so long as the compiler had independently gathered the data. ${ }^{19}$ Feist establishes as a matter of statutory as well as constitutional interpretation that a compilation will qualify for copyright only if it displays originality and a modicum of creativity in the selection or arrangement of its component data. ${ }^{20}$ The white pages at issue manifested neither selectivity nor creative arrangement: it was an exhaustive collection, routinely arranged, of names, towns, and telephone numbers of subscribers in the

14. 111 S. Ct. 1282 (1991).

15. See id. at 1286.

16. See id.

17. See Rural Tel. Serv. Co. v. Feist Publications, Inc., 663 F. Supp. 214, 217-19 (D. Kan. 1987), aff'd, 916 F.2d 718 (10th Cir. 1990), rev'd, 111 S. Ct. 1282 (1991).

18. See Feist Publications, lnc. v. Rural Tel. Serv. Co., 111 S. Ct. 40, 40 (1990). Althougb the certiorari petition posed three questions, the Court limited its grant to the last: "Does the copyright in a telephone directory by the telephone company prevent access to that directory as a source of names and numbers to compile a competing directory, or does copyright protection extend only to the selection, coordination, or arrangement of those names and numbers?" See id.; see also Petition for Writ of Certiorari, Feist Publications, lnc. v. Rural Tel. Serv. Co., 111 S. Ct. 1282 (1991) (No. 89-1909) (containing questions presented to Court).

19. See, e.g., Hutchinson Tel. Co. v. Fronteer Directory Co., 770 F.2d 128, 132 (8th Cir. 1985); Jeweler's Circular Publishing Co. v. Keystone Publishing Co., 281 F. 83, 88 (2d Cir.), cert. denied, 259 U.S. 581 (1922).

20. See Feist Publications, Inc. v. Rural Tel. Serv. Co., 111 S. Ct. 1282, 1296 (1991). 
locality. ${ }^{21}$

In the wake of Feist, it is important to evaluate what kinds of compilations may still he deemed to incorporate original authorship. Although the controversy in Feist concerned only the white pages, the decision's standard of originality-emphasizing creativity of selection or arrangement of data-threatens to remove other classes of compilations from copyright as well. It is equally if not more important to discern the post-Feist scope of protection of compilations, that is, the acts of copying that will he deemed to infringe an original compilation. Feist's conception of the scope of copyright in works of information extends the importance of the decision far beyond the class of compilations too lacking in creativity to qualify for copyright at all. Even were one to conclude that only the white pages have been completely expelled from copyright, Feist, by allowing protection only for the compiler's "original contributions," calls into question the ability of copyright still to secure meaningful coverage to those compilations that do meet the initial test of copyrightability.

\section{A. Originality in Fact Compilations After Feist}

The Feist opinion is more explicit in describing what is not original than in delineating what is. The Court made clear that expenditure of "sweat of the brow" does not make a work original, no matter how useful the ensuing production. The Court set forth its distinction between copyrightable creation and mere utility quite plainly: "[plaintiff] expended sufficient effort to make the white pages directory useful, but insufficient creativity to make it original."22 The compilation was "entirely typical," "a garden-variety white pages directory, devoid of even the slightest trace of creativity" because its selection of facts about telephone subscribers "could not be more obvious: it publishes the most basic information," and because the "age-old practice" of alphabetical arrangement was "commonplace," not "remotely creative," indeed "practically inevitable."23 Plaintiff's work fell into a category of works in which "the creative spark is so utterly lacking or trivial as to be virtually nonexistent." Henceforth, to be "original," and therefore copyrightahle, whatever the effort devoted to compile a work of information, and however useful the work may be, the work must display "more than a de minimis quantum of creativity."24

In holding the white pages directory not copyrightahle, the Court employed terms that evoke the patent law standards of protectability. ${ }^{25}$

21. See id.

22. Id.

23. Id. at 1296-97.

24. Id.

25. See 35 U.S.C. $\S \S 102,103$ (1988); cf. Lotus Dev. Corp. v. Paperback Software Int'1, 740 F. Supp. 37, 62-68 (D. Mass. 1990) (upholding copyright in Lotus 1-2-3 screens and command keys on grounds, inter alia, that these features were nonobvious); 
The Court's word choice might best be viewed as rhetorical excess; it should not prompt lower courts to infer that to be deemed "original" a compilation must now be novel and nonobvious. ${ }^{26}$ Were Feist so interpreted, then the Court would not only have eliminated the more commodious "sweat" standard of protection, it would also have initiated a different dual copyright system, requiring compilations to meet a higher standard of authorship than is imposed on other kinds of works. ${ }^{27}$ But the Feist Court did not purport to abandon more traditional criteria. The 1976 Copyright Act grants exclusive rights to "original works of authorship," and lists a variety of categories of such works. ${ }^{28}$ The statute explicitly includes compilations among covered subject matter. ${ }^{29}$ The Court relied on the statutory definition of a compilation as "a work formed by the collection and assembling of preexisting materials or of data that are selected, coordinated, or arranged in such a way that the resulting work as a whole constitutes an original work of authorship,"30 and particularly stressed the elements of selection and arrangement. ${ }^{31}$

Of the two elements of originality, the arrangement criterion may prove the more difficult for information compilations to satisfy. Many compilations are likely to be organized alphabetically or chronologically, arrangements too commonplace to meet the Feist "modicum of creativity" criterion. The arrangement of other compilations might be deemed virtually "inevitable" to the nature of the subject, such as reports of judicial decisions organized by hierarchy of jurisdiction. Still other arrangements could be considered functional to the material,

Russ VerSteeg \& Paul K. Harrington, Nonobviousness as an Element of Copyrightability? (Or, Is the Jewel in the Lotus a Cubic Zirconia?), 25 U.C. Davis L. Rev. 331, 372-82 (1992) (criticizing nonobviousness discussion in Lotus).

26. See Key Publications, Inc. v. Chinatown Today Publishing Enters., 945 F.2d 509,513 (2d Cir. 1991) ("for purposes of copyright, originality is not synonymous with novelty"), discussed infra notes $62-65$ and accompanying text.

27. It seems more reasonable, however, to conclude that if novelty and nonobviousness are conditions sufficient to establish originality, they are not necessary to it. A requirement that a compilation sparkle (however dimly) with creativity is still a considerably lesser standard than one requiring it to flash with genius. Cf. Graham v. John Deere Co., 383 U.S. 1, 15 (1966) (replacing "flash of creative genius" test announced in Cuno Eng'g Corp. v. Automatic Devices Corp., 314 U.S. 84, 91 (1941), with "nonobviousness" criterion in patent law).

28. 17 U.S.C. $\S 102(\mathrm{a})$ (1988).

29. See id. $\S 103$.

30. Id. § 101; accord Feist Publications, Inc. v. Rural Tel. Serv. Co., 111 S. Ct. 1282,1293 (1991).

3I. The Court sometimes referred to a requirement of selection and arrangement, see, e.g., Feist, $111 \mathrm{~S}$. Ct. at 1295, and other times to a test of selection or arrangement, see, e.g., id., but in the statute, the terms are presented as alternative, not cumulative, criteria. It seems fair to conclude that the Feist Court intended to apply the statute as written, not to announce a considerably more stringent double criterion. See id. at 1293-97. The Court did not analyze the "coordination" criterion, except to reject the argument that the assignment of telephone numbers to names and towns constituted original "coordination." Id. at 1297. 
such as the classification of businesses in a yellow pages directory. ${ }^{32}$ There may be more than one way to describe and categorize the listings, but the greater the variety of classifications, the more frustrated the user of the yellow pages is likely to become. Some uniformity of listings may be necessary to "user friendliness." As the number of possible combinations of classifications decreases, however, so do opportunities for creativity in devising organizing designations. Finally, some compilations, particularly computerized databases, may lack any "arrangement," for they are designed to permit the user to impose her own search criteria on the mass of information.

The selection criterion may prove more susceptible to infusions of creativity. Feist does not challenge or undermine the long-standing principle that a subjective selection of information, such as the "best" baseball players ${ }^{33}$ or the most socially prominent families, ${ }^{34}$ satisfies the minimal creativity standard. Moreover, the selection need not be intimately personal, so long as it can be shown to have resulted from thoughtful evaluation and choice. As the Second Circuit has stated in a post-Feist directory decision, "[s]election implies the exercise of judgment in choosing which facts from a given body of data to include in a compilation." 35 But this principle may be of little assistance to compilers who eschew selectivity in favor of comprehensiveness. The exhaustive compilation may be most attractive to the user, who need not fear that potentially desirable information has been excluded according to the compiler's perhaps unwanted selection criteria. Yet under Feist, this kind of compilation, however useful and sought-after, is most vulnerable to the charge that it lacks originality. Feist thus poses the dilemma: How can one achieve original selection within an exhaustive compilation of facts?

If the compilation includes all information within the universe surveyed, perhaps originality might inhere in the selection of the universe. Although the white pages detail a banal universe-all telephone sub-

32. But see Key Publications, Inc. v. Chinatown Today Publishing Enters., Inc., 945 F.2d 509, 5I5-16 (2d Cir. I99I) (post-Feist case finding minimal originality in nomenclature of yellow pages business classifications); Bellsouth Advertising \& Publishing Corp. v. Donnelley Info. Publishing Co., 933 F.2d 952, 957-58 (1 th Cir. 1991) (same).

33. See Eckes v. Card Prices Update, 736 F.2d 859, 862-63 (2d Cir. 1984) (listing of baseball cards, including sub-listing of "premium" cards).

34. See List Publishers Co. v. Keller, 30 F. 772, 773-74 (C.C.S.D.N.Y. 1887).

35. Key Publications, 945 F.2d at 513, 514 (classified directories of Chinese-American businesses). Plaintiff's directory was deemed copyrightable because she excluded enterprises she believed would not remain in business. The court noted that her testimony "indicates thought and creativity in the selection of businesses included." Id. at 513. Elsewhere in the opinion, the Second Circuit characterized the originality requirement as satisfied by "de minimis thought." Id. at 514; see also Mid America Title Co. v. Kirk, No. 86-C-2853, 1991 U.S. Dist. LEXIS 11168 at *8-99 (N.D. 1ll. Aug. 7, 1991) (denying summary judgment on ground that plaintiff's "use of judgment in determining which land title facts should be included" was question of fact). 
scribers within a given geographical area-some other universes might be sufficiently offbeat to be minimally creative. For example, a directory of all American and Canadian manufacturers of toothbrushes with biodegradable bristles seems neither "commonplace" nor "obvious." The original contribution here therefore would be the identification of the general kind of data to include in an exhaustive compilation. Because copyright inheres in the original contribution, protection would attacb to the selected universe.

But this object of protection engenders another impediment to copyright protection. However inventive the identification of the universe, its designation should be deemed an "idea" and held unprotectable on that ground. ${ }^{36}$ In copyright law, an "idea" is not an epistemological concept, but a legal conclusion prompted by notionsoften unarticulated and unproven-of appropriate competition. ${ }^{37}$ Thus, copyright doctrine attaches the label "idea" to aspects of works which, if protected, would (or, we fear, might) preclude, or render too expensive, subsequent authors' endeavors. ${ }^{38}$ In our example, the universe would be ruled an "idea" because were it not, no second-comer could, without her predecessor's authorization, compile her own biodegradable tootbbrush directory-even if she independently gathered the listings. ${ }^{39}$ In effect, the copyright would shield the first compiler not only against second-comers who free ride on the first compiler's researches, but even against those who perform their own "industrious collection," 40 so long as the subject-matter area is the same. ${ }^{41}$ Copyright protection for the designation of a compilation's universe thus

36. See 17 U.S.C. $\S 102$ (b) (1988) (copyright protection does not extend to ideas).

37. See, e.g., Lotus Dev. Corp. v. Paperback Software Int'l, 740 F. Supp. 37, 65-68 (D. Mass. 1990) (user interface of Lotus 1-2-3 held not an "idea"; the court considered, inter alia, availability of alternative interfaces to competitors, and rejected defendant's argument that it could not effectively compete without copying plaintiff's interface).

38. See, e.g., William Landes \& Richard Posner, An Economic Analysis of Copyright Law, 18 J. Legal Stud. 325, 347-49 (1989); Jessica Litman, The Public Domain, 39 Emory L.J. 965, 1010-16 (1990).

39. In theory, if the second compiler independently conceived of the toothbrush universe, there could be no infringement, for infringement arises from copying the prior original work of authorship. However, the second-comer may find it difficult to prove that she had no access to the prior directory, particularly if it was widely disseminated. See generally Litman, supra note 38, at 1022 ("Disproving access is, in most cases, no longer possible.").

40. Cf. Rockford Map Publishers, Inc. v. Directory Serv. Co. of Am., 768 F.2d 145, 149 (7th Cir. 1985) ("The right to 'check back' does not imply a right to start with the copyrighted work. Everyone must do the same basic work, the same 'industrious collection.' ").

41. Cf. Eisenschiml v. Fawcett Publications, 246 F.2d 598 (7th Cir. 1957) (copyright in biography of Abraham Lincoln does not give author a monopoly in the biographical subject); Echavarria v. Warner Bros. Pictures, lnc., 12 F. Supp. 632, 638 (S.D. Cal. 1935) (copyright in a novel about Generals Grant and Lee cannot confer an exclusive right to fictionalize the Civil War). 
disables production of competing works, without furthering the policies underlying sweat copyright.

An exhaustive compilation may nonetheless offer possibilities for exercise of selective judgment within the nonselective framework. For example, the exhaustive listing of American and Canadian biodegradable toothbrush manufacturers can contain complementary information, whose selection could be deemed "creative." Thus, if a directory of this kind included "the most basic information" of name, address and telephone number, the inclusion of all or some combination of additional information, such as number of employees, quantities of toothbrushes produced, average production time, and amount of time required for the brushes to biodegrade, might be less "commonplace." Moreover, the directory might add subjective information such as a rating of the quality of the toothbrushes or of the creditworthiness of the manufacturer. ${ }^{42}$ Database producers refer to this kind of complementary information as "value added." 43

For many post-Feist information compilations, the decision to add this kind of "value" may be driven more by a desire to achieve creative originality than by consumer demand. That is, the consumer may simply desire an exhaustive compilation of names and addresses for a given sector, ${ }^{44}$ but the post-Feist compiler who still wishes to obtain copyright protection, knowing that such a compilation may not be found "original," will feel obliged to add "original" content to the collection of facts. This kind of value added of course also adds expense, and thus augments the cost of the database without a concomitant gain to its users. Despite its policy of encouraging free, or at least cheap, access to information, Feist may result in making the creation of compilations and access to them more expensive and less efficient.

As a general rule, one might propose that the greater the possible number of combinations of data, the more likely the selection of any particular combination will be deemed minimally creative. In support of this proposition, one might draw on a recent post-Feist ruling of the Second Circuit in a controversy concerning baseball pitching forms. In Kregos $v$. Associated Press, ${ }^{45}$ the court held that plaintiff compiler's choice of nine categories of statistical information manifested originality. Plaintiff was the first compiler of pitching forms to include nine catego-

42. Cf. Eckes v. Card Prices Update, 736 F.2d 859, 863 (2d Cir. 1984) (inclusion of sub-set of 5000 subjectively designated "premium" baseball cards within exhaustive list of 18,000 baseball cards appears to have rendered compilation copyrightable as a whole). However, addition of subjective information does not confer copyright upon the "common place" elements. See infra notes 58-61 and accompanying text.

43. See, e.g., William P. Farley, Industry Impact of Feist, in 'Fact' and Data Protection After Feist 41, 42 (Jon A. Baumgarten ed., 1991).

44. This kind of compilation is referred to in the industry as a "Dragnet compilation: 'Just the facts.'" Steven Metallitz, Vice President and Counsel, Information Industry Association, Remarks (Sept. 20, 1991).

45. 937 F.2d 700 (2d Cir. 1991). 
ries of information; prior compilers of such forms had included only three or four. Moreover, plaintiff was the only one to select certain categories within the nine for inclusion on any pitching form. His choice of the number and nature of statistical categories to include was thus novel and unique. ${ }^{46}$ Rejecting defendant's charge that plaintiff was endeavoring to protect raw information, the court observed that even were it true, as defendant asserted, that there were only twenty categories of potentially pertinent statistical information, plaintiff nonetheless had ample opportunity to exercise creative selection. ${ }^{47}$ The court calculated that a person wishing to compile a nine-category pitching form from a pool of twenty statistical categories could choose from 167,960 possible combinations. ${ }^{48}$

Notably, some of the statistical categories selected in Kregos, such as win-loss record and earned run average, may have been "commonplace" or "inevitable" to a pitching form designed to help baseball fans predict which of the pitchers was more likely to win the game. Nonetheless, what counted in the court's analysis of originality was not the originality of each category, but the overall combination of chosen categories. By the same token, virtually any information compilation will contain data whose inclusion is required by the nature of the compilation. Evaluation of the originality of the selection should focus on the selection as a whole.

Kregos' clarification of the post-Feist originality standard is not unalloyed. The court stressed the novelty of plaintiff's compilation of a nine-category form. The court emphasized the uniqueness of plaintiff's endeavor in order to demonstrate that, unlike the Feist white pages, plaintiff's form was not "entirely typical," or "garden variety," or "obvious." 49 Doubtless, the court did not intend to impose a novelty condition on originality. Nonetheless, one may fear future confusion of the standards. Today, a court may say, "Novelty is not required, but if the selection effected by the compiler is novel, it follows that it is also original." Tomorrow, will a court declare, "This compilation's selection is not novel, hence it cannot be original"?

\section{B. Scope of Protection of Original Compilations}

Despite the importance of the threshold inquiry into copyrightability, the more significant question for most information compilers will be the scope of protection accorded their work. This is because copying may occur in many varieties. Verbatim reproduction is only one variety, and it may not occur most frequently. Rather, a secondcomer may compile a competing work by combining copied portions of

46. See id. at 704-05.

47. See id.

48. See id. at 704 n.3.

49. Id. at $704-05$. 
a prior directory or database with independently gathered data. Alternatively, he may incorporate copied data in a work that does not supplant the first compiler's production. In either event, the second-comer is availing bimself of the first compiler's labors. The extent to which copyright secures those labors influences the initial decision whether or not to expend them.

Although the Supreme Court granted certiorari in Feist to determine the proper scope of protection of a compilation, ${ }^{50}$ it decided the case on grounds of copyrightability, and thus never explicitly ruled on scope. Nonetheless, the decision suggests an answer to the scope question: "Even if the compilation is deemed original, what kind of copying will be held to infringe it?" The answer appears to be: "Virtually none, short of extensive verbatim copying."

The Court has endorsed the "thin" copyright concept: "Notwithstanding a valid copyright, a subsequent compiler remains free to use the facts contained in another's publication to aid in preparing a competing work, so long as the competing work does not feature the same selection and arrangement."51 The Court has thus rejected the substantial prior "sweat of the brow" jurisprudence that found copyright infringement when a competitor copied previously gathered information in order to save itself the time, labor and expense of compiling its own information. ${ }^{52}$ Indeed, Justice O'Connor's opinion appears to enshrine a policy of free-riding in the Constitution. Use of the fruit of the compiler's labor without compensation, her opinion declares, is " 'the essence of copyright,' and a constitutional requirement."'53

Of course, an equally constitutional "essence of copyright" is that authors enjoy the "exclusive Right to their Writings," for the author's monopoly is thought to encourage production, and thereby to "promote the Progress of Science."54 In the logic of Feist, the competitor's constitutional free ride can be reconciled with the author's constitutional monopoly by clearly distinguishing unprotectable "labor" from proprietary "original" contributions. But this distinction may be more appealing in theory than in practice. Perhaps not surprisingly, pre-Feist courts often confounded the two, ${ }^{55}$ for they perceived that copyright supplied a necessary incentive to the expenditure of sweat required to

50. See supra note 18 .

51. Feist Publications, Inc. v. Rural Tel. Serv. Co., 111 S. Ct. 1282, 1289 (1991).

52. See, e.g., Rockford Map Publishers, lnc. v. Directory Serv. Co., 768 F.2d 145, 149-50 (7th Cir. 1985), cert. denied, 474 U.S. 1061 (1986); Leon v. Pacific Tel. \& Tel. Co., 91 F.2d 484, 487 (9th Cir. 1937); Sampson \& Murdock Co. v. Seaver-Radford Co., 140 F. 539, 542-43 (1st Cir. 1905).

53. Feist, 111 S. Ct. at 1290 (quoting Harper \& Row Publishers, lnc. v. Nation Enters., 471 U.S. 539, 589 (1985) (Brennan, J., dissenting)) (citations omitted).

54. U.S. Const. art. I, § 8, cl. 8.

55. See, e.g., United Tel. Co. v. Johnson Publishing Co., 855 F.2d 604, 607 (8th Cir. 1988); National Business Lists, Inc. v. Dun \& Bradstreet, Inc., 552 F. Supp. 89, 91-92 (N.D. Ill. 1982). 
produce the compilation. ${ }^{56}$ Remarkably, Feist grossly neglects copyright's incentive role. ${ }^{57}$ That acknowledgment might have led the Court to a more nuanced analysis. Instead, the opinion betrays no hesitation in proposing an apparently clear-cut principle to separating labor from orginality: "No matter how original the format [selection and/or arrangement], however, the facts themselves do not become original through association." 58 In other words, there is no infringement unless the defendant has copied the original contribution: "[T]he copyright is limited to the particular selection or arrangement. In no event may copyright extend to the facts themselves."59 Moreover, while prior lower court decisions may have found originality in the compiler's contribution of "sweat," 60 under Feist, the investment of labor or resources can no longer constitute the "original" element of the work. Rather, courts must look to the selection or arrangement alone.

Thus, if the original contribution is the compilation's arrangement, then copying the facts, but organizing them differently, will not be infringement. If the original contribution is the selection, then copying nonselective aspects of the compilation will not be infringement. For example, if a competitor reproduces all the address listings of the biodegradable toothbrush directory, but leaves behind all the selective sub-categories of information, as well as any subjective rankings, then the competitor has not copied the original material. The first toothbrush directory compiler may have added enough selective value to make the compilation copyrightable as a whole, but the copyright will not extend backward to prohibit reproduction of the rawer aspects of the data (which, as we saw earlier, may well be the part of the data that consumers most desire). The Second Circuit's Kregos decision is instructive here as well. Having held that originality inhered in the particular combination of nine statistical categories, the court, remanding to the district court, expressed considerable doubt that defendant, having copied only six of the nine categories, could be found to have infringed. ${ }^{61}$

More recently, the Second Circuit revisited the scope of protection

56. See generally National Business Lists, 552 F. Supp. at 93-95 (concluding from review of numerous compilation copyright cases that sweat "has, through copyright, been accorded a measure of protection because that is the only protection that is meaningful").

57. The Court observed "in passing" that Kansas regulations required Rural to create the directory as part of its telephone service franchise. See Feist, $111 \mathrm{~S}$. Ct. at 1296-97. This observation, however, concerned not incentives to create, but the nonoriginality of Rural's "selection" of names. See id.

58. Feist, 111 S. Ct. at 1289.

59. Id. at 1290; accord 17 U.S.C. $§ 103$ (1988) ("The copyright in a compilation ... extends only to the material contributed by the author of such work, as distinguished from the preexisting material ....").

60. See cases cited supra note $\mathbf{5 5}$.

61. See Kregos v. Associated Press, 937 F.2d 700, 709-10 (2d Cir. 1991). Defendant had initially copied all nine categories; with respect to this version of 
issue in a controversy involving a yellow pages directory. ${ }^{62}$ Acknowledging that after Feist the scope of copyright protection is "thin," the court cautioned, "we do not believe it is anorexic."63 Under this slender but not undernourished infringement standard, an information compiler must show "substantial similarity between those elements, and only those elements, that provide copyrightability to the allegedly infringed compilation. ... The key issue is not whether there is overlap or copying but whether the organizing principle guiding the selection of businesses for the two publications is in fact substantially similar."64 In practice, this appears to mean that unless the arrangement is substantially duplicated, or unless there is close correspondence of the selection of information in plaintiff's and defendant's works, no infringement can be found. The court stressed that although defendant had copied from plaintiff's yellow pages directory, "no suhstantial categories and their listings have been taken wholesale."65 Under the court's approach, it seems that a second-comer may compile a directory taking some subset of each category of plaintiff's listings, so long as the second-comer does not replicate most of the categories. In other words, a second-comer may select and reshuffle from within a prior compilation; these acts of copying do not appropriate the "original" contributions of the first compiler.

Would the result be different if the second-comer first copied the prior compilation in its entirety, for example by downloading, and then extracted or reorganized information so that the end product were purged of the first-comer's original contributions? Under Feist, the final version would not be infringing, but what of the initial downloading? Establishment of the initial copy enabled the second-comer to create its reshuffled compilation, at far less expense and effort than that expended by the first compiler to gather the information. But if, as Justice O'Connor has declared, the Constitution favors this kind of free-riding, then first compilers may be obliged to tolerate copying predicate to reshuffling. At least, according to this view, any remedy accorded against initial copying should not preclude exploitation of the noninfringing fruits of the copying. Otherwise, reprimanding initial copying would prove a pretext to protecting sweat. Such protection clashes with Justice O'Connor's assertion that appropriation of sweat "is neither unfair nor unfortunate. It is the means by which copyright advances the progress of science and art." 66

defendant's form, the Second Circuit indicated infringement should be found. See id. at 709.

62. See Key Publications, Inc. v. Chinatown Today Publishing Enters., 945 F.2d 509, 511 (2d Cir. 1991).

63. Id. at 514.

64. Id. at 514-16.

65. $1 d$.

66. Feist Publications, Inc. v. Rural Tel. Serv. Co., 111 S. Ct. 1282, 1290 (1991). If the copied compilation displayed no originality, then, under Feist, no claim would lie 
Nonetheless, judicial inclination to reprimand sweat theft remains strong. The Eleventh Circuit demonstrated its resistance to the abolition of sweat copyright in its post-Feist decision in Bellsouth Advertising $\mathfrak{E}$ Publishing Corp. v. Donnelley Information Publishing Co. ${ }^{67}$ There, defendant Donnelley, a publisher of phone books and similar compilations, had obtained by license from plaintiff Bellsouth a list of Bellsouth's yellow pages subscribers. The license entitled Donnelley to prepare a yellow pages for the Greater Miami area. Donnelley, however, also loaded the Bellsouth subscriber information into its computer and created sales lead sheets that permitted it to solicit additional advertising from Bellsouth's customers. In addition, Donnelley's yellow pages directory reproduced much of Bellsouth's format. ${ }^{68}$

In response to Bellsouth's copyright infringement claim, Donnelley emphasized that it had copied only nonprotectable information. The court sustained Bellsouth's argument that the organization of its yellow pages was "original," and that Donnelley's yellow pages substantially reproduced Bellsouth's original format. ${ }^{69}$ The court further held that Donnelley's sales lead sheets, albeit arranged differently, captured Bellsouth's organization because Donnelley had reproduced the codes Bellsouth used to classify its listings. Donnelley could have used these codes to reconstruct the organization of the Bellsouth directory. ${ }^{70}$ The court may have sensed some weakness in this infringement-by-reference approach, for it noted: "The district court's finding that this particular act [establishing sales lead sheets] was a substantial appropriation, hence copying, might not be as felicitous had the sales lead sheets not been derived from the initial copy which was entered into the computer data base and fixed on the magnetic tape."71 In other words, the element buttressing the infringement finding was the creation of an initial integral copy. Thus even after Feist, a court seeking to secure a first compiler's sweat might read Bellsouth as an encouraging example of finding liability when the final product forgoes the prior work's "original" contributions, so long as that product derived from a preparatory infringement. ${ }^{72}$

even for making the single copy. If the compilation passed the minimal originality threshold, award of damages for the one copy would be consistent with Feist, but damages for the fruits of the copying-the otherwise noninfringing second compilation-would not.

67. 933 F.2d 952 (I Ith Cir. I99I).

68. See id. at 956.

69. See id. at 958-60.

70. See id. at 959; cf. West Publishing Co. v. Mead Data Cent., 799 F.2d 1219, 1226-27 (8th Cir. 1986) (employing similar infringement-by-reference approach to find LEXIS "star pagination" of case reports- to reflect page breaks in the West reporter system-reproduced the "arrangement" of West volumes), cert. denied, 479 U.S. 1070 (I987).

71. Bellsouth, 933 F.2d at 959 n.20.

72. Bellsouth's reasoning suggests an argument against reverse-engineering computer programs. Even if the program that results from decompiling plaintiff's work 
Bellsouth notwithstanding, the proper post-Feist scope of copyright (at least as intended by the Supreme Court) would not permit protection to extend to the facts themselves. Thus, one who extracts information, but not its organization, or who does not substantially emulate the first compiler's selection, cannot be a copyright infringer. That person will, however, have gained a significant benefit from the first-comer without compensating her. Absent protection for the effort and expense of compiling information, one may fear the substantial diminution of incentives to invest in compiling information. ${ }^{73}$ If copyright, despite its constitutional purpose of promoting the progress of knowledge, can no longer afford adequate incentives to information gathering, one should inquire into the availability of effective protection at state law. State law misappropriation doctrines may supply a claim, ${ }^{74}$ but federal preemption doctrines may also nullify the claim.

\section{State Law Anticopying Protection and Its Federal PREEMPTION}

This Part briefly considers state law misappropriation claims against copying compilations, and more extensively discusses the susceptibility of those claims to federal preemption. I will examine three different sources of federal preemption: the preemption section of the

does not reproduce plaintiff's code or plaintiff's structure, sequence, and organization, an infringement claim might lie if defendant first made an unauthorized copy of plaintiff's program in order to decompile it. However, under 17 U.S.C. $\$ 117$ (1988), as interpreted in Vault Corp. v. Quaid Software, Ltd., 847 F.2d 255, 262 (5th Cir. 1988), that argument would be unavailing. Section 117 allows the owners of a copy of a computer program to make a further copy in conjunction with the operation of the machine. In Vault, the appellate court held this provision to permit decompilation of the program. On the other hand, if defendant were not the lawful owner of the copy of the program used to establish the decompilation, section 117 would not apply.

73. See, e.g., Farley, supra note 43 , at 43 ("Until the scope of protection is clarified [in favor of protection], there will be greater difficulty in justifying major investments in certain compilation products. In other words, some useful compilations will not be published."); see also Philip H. Miller, Note, Life After Feist: Facts, the First Amendment, and the Copyright Status of Automated Databases, 60 Fordham L. Rev. 507, 521-23 (1991) (Feist jeopardizes incentives to create databases).

74. An information proprietor may also have a state law contract claim if the copyist breached the conditions under which he gained access to the copied material. In the wake of Feist, contract claims may present the primary source of protection of information. See, e.g., Farley, supra note 43, at 42; Ronald S. Rauchberg, Structuring Contracts for Fact Protection, in 'Fact' and Data Protection After Feist, supra note 43, at 109; Memorandum from Gardner, Carton \& Douglas, Contract Provisions Restricting Uses of Databases, reprinted in 'Fact' and Data Protection After Feist, supra note 43, at 397. However, the protection afforded by contract law may be incomplete. See Creation and Commercial Value, supra note 6, at 1918-22 (identifying shortfalls of contract and self-help remedies); Farley, supra note 43 , at 42 (arguing that "[ $t$ ]here is some question about the enforceability of some forms of contract"); Rauchberg, supra, at 110-12 (discussing problems with enforcement of contracts of adhesion). 
1976 Copyright Act; 75 congressional "occupation of the field" resulting from the overall structure of the copyright statute and of the PatentCopyright Clause; and Commerce Clause prohibitions on state interference with national trade in intellectual property. The last variety of preemption can also be viewed in terms of sister-state federalism: states must refrain from regulating intellectual property when the impact of local restrictions transcends local boundaries.

\section{A. State Common-Law Claims Against Misappropriation of Information}

Misappropriation is a broad anticopying doctrine. "The misappropriation doctrine potentially is available whenever a person imitates or duplicates a work developed at the expense of another."76 It was devised by the Supreme Court in International News Service v. Associated Press, 77 a case concerning copying of information. Plaintiff Associated Press' (AP) European correspondents sent news of the First World War to AP's East Coast bureaus. AP published the bulletins on the East Coast without notice of copyright, and as a result dedicated the bulletins to the public domain. AP's rival, the International News Service (INS), was unable to send reports from England to the United States, but compensated for its lack of foreign bulletins by copying AP's East Coast reports and relaying them to INS Midwest and West Coast papers, simultaneously or even ahead of their receipt by AP's local counterparts.

Although AP could claim no copyright in its bulletins, the Court nonetheless held that INS' copying should be restrained. AP's substantial investment of "enterprise, organization, skill, labor, and money" warranted recognition of a "quasi-property" right in the dissemination of the uncopyrightable information. ${ }^{78}$ The Court coined the "quasi-" qualification of the property right in order to distinguish it from more genuine, or at least more robust, forms of property rights: this property right could be effective against competitors, but not against the public at large. Moreover, the duration of the right was fleeting indeed, lasting only for the time needed to complete the process of nationwide dissemination of the information. ${ }^{79}$

The facts in INS were peculiar and the Court's enunciation of a "quasi-property" right was tailored to those facts. Nonetheless, much of the Court's language strained or even burst the bounds of the individual case. In the course of the majority opinion, the Court invoked

75. 17 U.S.C. § 301 (1988).

76. David Shipley, Refusing to Rock the Boat: The Sears/Compco Preemption Doctrine Applied to Bonito Boats v. Thunder Craft, 25 Wake Forest L. Rev. 385, 413 (1990).

77. 248 U.S. 215 (1918).

78. 1d. at 236.

79. See id. at 237. 
some agricultural metaphors that have taken root in the rhetoric of unfair competition. The Court declared:

[D]efendant ... admits that it is taking material that has been acquired by complainant as the result of organization and the expenditure of labor, skill, and money, and which is salable by complainant for money, and that defendant in appropriating it and selling it as its own is endeavoring to reap where it has not sown, and by disposing of it to newspapers that are competitors of complainant's members is appropriating to itself the harvest of those who have sown..$^{80}$

Confined to its facts, INS concerned interference with publication. However, thanks in part to its fertile allusions, INS has come to stand for a general common-law property right against "misappropriation" of commercial value.81 Whose common law? A 1918 decision, INS created general federal common law of the type divined by federal courts under Swift $v$. Tyson, ${ }^{82}$ a kind of federal common law extinguished by Erie. ${ }^{83}$ Nonetheless, INS has blossomed in state courts, ${ }^{84}$ and might be thought to furnish a legal doctrine supporting extensive protection of informational works, particularly given the Supreme Court's emphasis on "expenditure of labor, skill, and money." 85

\section{B. Preemption Under Section 301 of the 1976 Copyright Act}

As a state law tort, however, misappropriation may find its usefulness as a protection against copying of information curtailed by federal preemption doctrines. The 1976 Copyright Act contains a preemption provision that prohibits state regulation when the following two features are joined: copyrightable subject matter and rights equivalent to rights afforded under the Copyright Act. ${ }^{86}$ This formula would seem

80. Id. at $239-40$.

81. For a discussion of the development of INS as a general misappropriation doctrine, see Douglas Baird, Common Law Intellectual Property and the Legacy of International News Serv. v. Associated Press, 50 U. Chi. L. Rev. 411, 415-23 (1983). For a critique of the Supreme Court's reasoning, and of the reasoning of subsequent applications of the INS doctrine, see Leo J. Raskind, The Misappropriation Doctrine as a Competitive Norm of Intellectual Property Law, 75 Minn. L. Rev. 875 passim (1991).

82. 4 I U.S. (16 Pet.) 1 (I842).

83. See Erie R.R. v. Tompkins, 304 U.S. 64, 78-80 (1938). Federal courts continue to announce federal common law rules that fill in the interstices of federal statutes. See, e.g., Community for Creative Non-Violence v. Reid, 109 S. Ct. 2166, 2179-80 (1989) (adopting Restatement of Agency test to define term "employee" in Copyright Act's work for hire provision); Carpenter v. United States, 484 U.S. 19, 26 (1987) (defining "property" under federal mail and wire fraud statutes).

84. See, e.g., Metropolitan Opera Ass'n v. Wagner-Nichols Recorder Corp., 101 N.Y.S.2d 483, 490-93 (Sup. Ct. 1950), aff'd, 107 N.Y.S.2d 795, 797 (App. Div. 1951).

85. International News Serv. v. Associated Press, 248 U.S. 215, 239 (1918); accord Board of Trade v. Dow Jones \& Co., 456 N.E.2d 84, 90-9l (Ill. 1983) (upholding misappropriation claim against Chicago Board of Trade for copying Dow Jones indexes as reference points for stock index futures contracts).

86. See 17 U.S.C. $\$ 301(\mathrm{a})-(\mathrm{b})$ (1988). For discussions of Copyright Act 
fatal to most misappropriation claims involving informational works.

First, respecting copyrightable subject matter, in copyright preemption analysis courts generally look to the work as a whole to determine its copyrightability. ${ }^{87}$ Here, the works themselvescompilations-are copyrightable subject matter, even if discrete elements of "misappropriated" information are not. Moreover, as the House Report to the 1976 Copyright Act states, "As long as a work fits within one of the general [copyright] subject matter categories . . . the [Copyright Act] prevents the States from protecting it even if it fails to achieve Federal statutory copyright because it is too minimal or lacking in originality to qualify." 88 Thus, whether the state claim alleges misappropriation of an entire compilation too uncreative to meet the Feist standard, or of information stripped of original copyrightable contributions, the claim would still address general copyright subject matter.

Similarly, with respect to the second prong of the 1976 Act preemption test, there is also equivalence of rights, at least at first blush. 1t does not matter that the particular reproductions at issue might not be infringing as a matter of copyright law. ${ }^{89}$ For example, the copying might be excused under the fair use doctrine. ${ }^{90}$ Nonetheless, the act state law targets is the creation of copies, and that act is equivalent to the exclusive right of reproduction under copyright. ${ }^{91}$

This analysis may require some qualifications with respect to both equivalence of subject matter and equivalence of rights. Regarding equivalence of rights, the legislative history of the 1976 Copyright Act suggests that certain misappropriation claims may survive copyright preemption. The legislative history, however, is muddled. The relevant statements about nonpreempted state claims describe a portion of the statute that would explicitly have preserved, inter alia, "rights against misappropriation not equivalent to any of such exclusive rights" under copyright. ${ }^{92}$ But Congress subsequently eliminated the

preemption of state law misappropriation claims, see, e.g., Howard B. Abrams, Copyright, Misappropriation and Preemption: Constitutional and Statutory Limits of State Law Protection, 1983 Sup. Ct. Rev. 509, 515-81; Paul Goldstein, Preempted State Doctrines, lnvoluntary Transfers and Compulsory Licenses: Testing the Limits of Copyright, 24 UCLA L. Rev. 1107, 1110-18 (1977); Robert A. Gorman, Fact or Fancy? The Implications for Copyright, 29 J. Copyright Soc'y 560, 598-610 (1982); Shipley, supra note 76 , at $386-91$.

87. See, e.g., Harper \& Row Publishers, Co. v. Nation Enters., 723 F.2d 195, 200 (2d Cir. 1983), rev'd on other grounds, 471 U.S. 539 (1985). See generally Gorman, supra note 86, at 604 (arguing that a work as a whole is not outside subject matter of copyright just because portions of it are uncopyrightable).

88. H.R. Rep. No. 1476, 94th Cong., 2d Sess. 131 (1976), reprinted in 1976 U.S.C.C.A.N. 5659, 5747.

89. See, e.g., Harper $\&$ Row, 723 F.2d at 201.

90. See 17 U.S.C. $\$ 107$ (1988).

91. See id. $\$ 106(1)$ (exclusive right of reproduction).

92. See H.R. Conf. Rep. No. 1733, 94th Cong., 2d Sess. 5 (1976), reprinted in 1976 U.S.C.C.A.N. 5810,5819 . 
language concerning this and other enumerated preserved state claims from the statute's preemption section. ${ }^{93}$ The value of this portion of the legislative history may therefore be thought somewhat dubious.

Nonetheless, were one to accord the legislative history some weight in determining Congress' intention to supplant state claims, that history offers some examples of surviving misappropriation claims that precisely respond to several of the problems at issue in this Article. The House Report states:

[S]tate law should have the flexibility to afford a remedy (under traditional principles of equity) against a consistent pattern of unauthorized appropriation by a competitor of the facts (i.e., not the literary expression) constituting "hot" news, whether in the traditional mold of Intermational News Service $v$. Associated Press, or in the newer form of data updates from scientific, business, or financial data bases. Likewise, a person having no trust or other relationship with the proprietor of a computerized database should not be immunized from sanctions against electronically or cryptographically breaching the proprietor's security arrangements and accessing the proprietor's data. . . . The proprietor of data displayed on the cathode ray tube of a computer terminal should be afforded protection against unauthorized printouts by third parties (with or without improper access), even if the data are not copyrightable. $^{94}$

This statement exhibits tolerance for certain kinds of state law protection of information.

The clearest case for survival of state claims is the INS situation itself: competitive and systematic interference with dissemination of unpublished, partially published, or access-controlled information, particularly when the timeliness of the information makes its commercial value of short duration. If the copying is not continuous, the misappropriation claim may be on weaker ground. ${ }^{95}$ In effect, going to the well once may not be actionable; only frequent return trips to another's product may enable the state claim to persist. Analytically, this distinction may appear deficient, for it suggests that the federal interest in free

93. See generally Alan Latman et al., Copyright for the Nineties 761-68 (3d ed. 1989) (discussing whether Congress intended section 301 of the 1976 Copyright Act to preempt state copyright law); Abrams, supra note 86 , at 537-50 (discussing legislative history of section 301 of the 1976 Copyright Act relating to misappropriation claims and copyright preemption); Ralph S. Brown, Jr., Unification: A Cheerful Requiem for Common Law Copyright, 24 UCLA L. Rev. 1070, 1089-1 102 (1977) (advocating that ambiguities in Copyright Act be resolved in favor of fostering greater uniformity to eliminate disparity among state law).

94. H.R. Rep. No. 1476 , supra note 88 , at 132 , reprinted in 1976 U.S.C.C.A.N. at 5748 (citation omitted).

95. See Ehat v. Tanner, 780 F.2d 876, 878 (10th Cir. 1985) (preempting misappropriation claim against unauthorized publication of laboriously gathered public domain documents), cert. denied, 479 U.S. 820 (1986). 
competition in uncopyrighted material shields occasional pilfering of information, but that this interest wanes when the theft is on a grand scale. ${ }^{96}$ The distinction recalls an attempt by the Second Circuit in a compilation case to separate copyrightable material from unprotectable facts. That court declared that no copyright could be claimed in "the sweat of a researcher's brow . . . ahsent, perhaps, wholesale appropriation." 97 In both cases, there is a federal interest in competition in the supply of information, but some law may ensure that the competition will be moderate.

After Feist, Congress may be constitutionally foreclosed from resorting to copyright law to prohibit copying information from compilations. But the sentiment may remain that once the copyist passes some undefined point of excess, there should be some source of anticopying relief. If copyright cannot supply the source, then perhaps state misappropriation law should. Nonetheless, the problem also remains, under the text of the 1976 Act's preemption section, that however "wholesale," immoderate, greedy, and unkind the copying, the conduct to be reprimanded by the state law misappropriation claim is simply copying, and on its face that is equivalent to the copyright right of reproduction.

Despite the doubtful persistence of state law misappropriation claims arising out of single acts of copying, the House Report details some specific acts of one-time copying that may still be subject to nonpreempted misappropriation claims: accessing the copied data by breaching a security system, or perhaps simply by printing out terminal-displayed information. ${ }^{98}$ However, to the extent that it divorces the print-out from illicit access, the second claim seems particularly vulnerable to preemption analysis under the text of section 301 . The substantive provisions of the copyright law make clear that copyright protection extends to works in any tangible medium of expression. 99 Therefore, the legislative history appears to be carving out an exception that amounts to making the medium the message. ${ }^{100}$ But preemption of state law seems no less applicable simply because the information is communicated by screen rather than by paper. If the

96. But see Bonito Boats, Inc. v. Thunder Craft Boats, Inc., 109 S. Ct. 971, 985-86 (1989), discussed infra notes 121-129 and accompanying text.

97. Eckes v. Card Prices Update, 736 F.2d 859, 862 (2d Cir. 1984); accord Key Publications, Inc. v. Chinatown Today Publishing Enters., 945 F.2d 509, 516 (2d Cir. 1991) (no infringement of original contributions to compilation found because "no substantial categories and their listings have been taken wholesale").

98. See supra text accompanying note 94 .

99. See 17 U.S.C. $\S 102$ (a) (1988).

100. Cf. Apple Computer, Inc. v. Franklin Computer Corp., 714 F.2d 1240, 1251 (3d Cir. 1983) (rejecting argument that program in object code, embedded on ROM and designed for communication with machine rather than human users, was uncopyrightable: "But the medium is not the message"), cert. dismissed, 464 U.S. 1033 (1984). 
only basis for making an exception is the medium of communication, a claim for misappropriation hardly seems "nonequivalent" to a copyright claim.

By contrast, a misappropriation claim combining allegations of copying with breach of an electronic security code may be less "equivalent" to a copyright claim. It offers an element distinct from the elements of a copyright claim; ${ }^{101}$ indeed, no showing of illicit access is required to establish a copyright violation. Moreover, such a claim enjoys common-law analogies. For example, the New York state courts have found violations of property interests when spectators at sporting events violated the conditions of access, or obtained illicit access, to the sports arena or event and then photographed or broadcast the events. ${ }^{102}$ In effect, in these instances copying is not the only complained-of wrong: the copying could not have occurred had defendant not engaged in other independently bad acts, such as trespass to land, or its modern electronic analog, "hacking" into an on-line service.

One might object that if in order to avoid preemption a state claim cannot be equivalent to a copyright action, perhaps the remedies cannot be equivalent either. Thus, perhaps the state claim should not entitle the first compiler either to an injunction against the second-comer or to damages equivalent to the second-comer's profits from exploitation of its compilation. ${ }^{103}$ Limiting the remedy for breaking into an electronically protected database to damages corresponding to the value of authorized access to the database, rather than to damages corresponding to the value of the hacker's exploitation of the compiled information, is an alternative. Such a state information protection claim would most likely resist copyright preemption because the claim proscribes only the breaking and entering into the security system. Nonetheless, limiting the remedy in this way is of questionable fairness. The cap on damages acts as a de facto compulsory license for hackers to access and exploit data maintained in a security-coded database. If

101. For elaboration of an "elements of the claim" approach to equivalence of rights and copyright preemption, see, e.g., 1 Nimmer on Copyright, supra note 7, $\S 1.01[B][1]$, at 1-13-1-14; Gorman, supra note 86, at 608-10.

102. See Rudolph Mayer Pictures v. Pathe News, 255 N.Y.S. 1016 (App. Div. 1932) (photographs of boxing match in Ebbets Field taken from roof of adjoining building, discussed in Madison Square Garden Corp. v. Universal Pictures, Co., 7 N.Y.S.2d 845, 851 (App. Div. 1938)); Twentieth Century Sporting Club v. Transradio Press Serv., 300 N.Y.S. 159, 161-62 (Sup. Ct. 1937) (violation of ticket's prohibition against broadcasting boxing match); see also Pittsburgh Athletic v. KQV Broadcasting Co., 24 F. Supp. 490, 491 (W.D. Pa. 1938) (defendant's observers stationed where they could see over the field enclosure in order to report play-by-play of baseball games held in plaintiff's ball park); cf. Madison Square Garden, 7 N.Y.S.2d at 850-52 (photographs that simulated Madison Square Garden's interior violated property right in sports arena's reputation).

103. Remedies for copyright infringement include injunctions, copyright owner's actual damages, and infringer's profits. See 17 U.S.C. $\$ \S 502,504$ (b) (1988). 
access to the data is itself wrongful, unauthorized users should not be entitled to the fruits of their illicit conduct.

It is worth noting that survival of a state information protection claim based on its nonequivalence to a copyright claim may encourage limitation of access to the information. If the claim resists preemption because it concerns breach of the conditions of access to the information, then it may follow that information providers had best erect barriers to making the information available. If the information is disseminated in a manner permitting easy access, for example in print media or in free-standing digital media such as CD ROM, then there can be no breaking and entering-type misappropriation claim. ${ }^{104}$ The safest medium of dissemination is likely to be on-line delivery, for it enables the information provider to impose conditions on the disclosure of the information. 'Thus, while Feist sought to promote the general and free access to information, the combination of copyright preemption of state law and Feist's retraction of copyright protection may create incentives for information providers to restrict access to information.

It may also be necessary to rethink the argument that state law misappropriation claims against copying information regulate subject matter within the scope of copyright protection, and to revisit the distinction between the "compilation" (copyright subject matter) and the "information" (not copyright subject matter). The prevailing view, before Feist, rejected state protection for uncopyrightable elements of a work of information on the ground tbat the work in which the information was compiled fit within copyright subject matter. ${ }^{105}$ Feist may have reinvigorated the contrary argument that the Copyright Act's exclusion of facts from the subject matter of copyright frees state law to protect the factual content of informational works. ${ }^{106}$ In declaring a "constitutionally mandated" standard of creative originality, the Supreme Court may be ruling that Congress does not have power under the PatentCopyright Clause to protect facts. ${ }^{107}$ Arguably, fact protection is a power the states never ceded to the federal government. ${ }^{108}$ If so, while

104. Information compilers might attempt to restrict access to the free-standing media of print and CD ROM by means of licensing agreements, where direct negotiations are possible, or by means of shrink-wrap licenses, when the access is by the general public. However, the enforceability of shrink-wrap licenses is questionable. See, e.g., Vault Corp. v. Quaid Software Ltd., 847 F.2d 255, 269-70 (5th Cir. 1988) (holding Louisiana "shrink-wrap license" statute preempted by federal Copyright Act).

105. See, e.g., Latman et al., supra note 93 , at 768-71.

106. See, e.g., Goldstein, supra note 86, at 1119 ; see also Feist Publications, Inc. v. Rural Tel. Serv. Co., 1 I 1 S. Ct. 1282, 1292 n.* (stating that INS "rendered judgment for [plaintiff] on noncopyright grounds that are not relevant here").

107. See discussion infra text accompanying notes $153-154$.

108. Cf. Goldstein v. California, 412 U.S. 546, 560 (1973) ("[U]nder the Constitution, the States have not relinquished all power to grant to authors the exclusive Right to their respective Writings.'"). 
federal copyright might cover the selection and arrangement of facts, only state law might protect the facts themselves. Therefore, the states could continue to protect information, so long as state regulation does not interfere with the general federal copyright scheme. ${ }^{109}$ That inquiry no longer addresses the Copyright Act's preemption section, but a broader analysis of federal preemption arising out of congressional occupation of the copyright field. ${ }^{110}$

\section{Congressional Occupation of the Field Under the Copyright Act and Under the Patent-Copyright Clause}

The failure of the Copyright Act's preemption section to delineate clearly the survival of state law protection of information shifts the federal preemption inquiry from that specific provision to the general structure and scheme of the Copyright Act. If the statute fails to manifest specific preemptive intent, that intent may be "implicitly contained in its structure and purpose." 11 Thus, one must inquire whether the Copyright Act as a whole reveals a federal policy favoring free copying of information.

Professor Gorman has argued persuasively that Congress, by providing in section 102(b) of the 1976 Copyright Act that protection does not extend to ideas and facts,

is not declaring such an idea [or fact] outside of the subject matter of copyright so much as it is affirmatively declaring-as clearly as it can, and for the clearest of reasons-that ideas [and facts] are free to be copied, adapted and disseminated, and that no court is to construe the federal copyright monopoly as inhibiting that freedom. The implication for state law is equally clear: neither can the states. ${ }^{12}$

Under this view of the statute, Congress has occupied the field of information protection: copyright covers the presentation of information (selection and arrangement), and no law may cover the information content itself. State protection of facts would therefore conflict with the congressional free-copying policy.

However, this argument ultimately may be more appealing than convincing. The admittedly confusing legislative history surrounding preemption of state misappropriation claims suggests that Congress did not perceive all state prohibitions on copying of information as inimical to the federal design. ${ }^{13}$ While the statutory copyright scheme

109. See id. at 559.

110. Cf. Abrams, supra note 86, at 566-75 (concluding section 301 does not exhaust preemptive reach of federal copyright policy, and considering instances of preemption outside of section 301).

111. Jones v. Rath Packing Co., 430 U.S. 519, 525 (1977).

112. Gorman, supra note 86 , at 604 . Professor Gorman further states, "The same can be said concerning the facts, principles, discoveries, and systems embodied in maps, directories, printed forms, and works of history or biography." ld.

113. See supra notes $92-96$ and accompanying text. 
may in general favor free reproduction of facts, it does not conclusively preclude state protections.

The Patent-Copyright Clause of the Constitution may supply a further source of preemption, for its designation of Congress to grant exclusive rights in writings and inventions might imply a rejection of state authority to offer parallel protection. Supreme Court intellectual property preemption decisions analyzing state anticopying remedies under the Patent-Copyright Clause have been inconsistent, to say the least. Over the last twenty-five years, the Court has moved from a nearly categorical prohibition of state anticopying remedies ${ }^{114}$ to tolerance of state regulation if the state law appeared to advance policies consistent with the federal patent or copyright regimes. ${ }^{115}$ Most recently, the Court has renewed its condemnation of state laws that forbid copying of useful articles. 116

In one of its 1964 Sears-Compco ${ }^{117}$ decisions, the Court announced: "To forbid copying [under state law] would interfere with the federal policy, found in [Article] I, [section] 8, [clause] 8, of the Constitution and in the implementing federal statutes, of allowing free access to copy whatever the federal patent and copyright laws leave in the public domain."118 The broad, open copying policy expressed in the Court's reference to the Patent-Copyright Clause implies that states may protect neither subject matter that Congress has elected to cover in the patent and copyright statutes, nor subject matter left unregulated by federal law, but within Congress' constitutional power to regulate.

However, the Court subsequently retreated from the Sears-Compco standard, holding that states might outlaw copying of subject matter within Congress' constitutional competence, but which Congress had not yet chosen to include within the copyright statute, so long as the state law did not siguificantly conflict with either the interests of other states or the federal statutory scheme. ${ }^{119}$ The following year, the Court seemed to abandon the Patent-Copyright Clause basis for preemption

114. See Sears, Roebuck \& Co. v. Stiffel Co., 376 U.S. 225, 231-33 (1964) (holding lllinois unfair competition statutes preempted in their application of anticopying remedies against "knock-off" lamp designs, but endorsing in dicta state remedies requiring truthful labelling of copied articles); Compco Corp. v. Day-Brite Lighting, Inc., 376 U.S. 234, 237-39 (1964) (same).

115. See Kewanee Oil Co. v. Bicron Corp., 416 U.S. 470, 480-92 (1974) (state trade secret protection of patentable subject matter held not preempted); see also Goldstein v. California, 412 U.S. 546, 567-72 (1973) (state copyright protection of sound recordings before inclusion of sound recordings within federal copyright subject matter not preempted because Congress did not occupy field of sound recordings regnlation).

116. See Bonito Boats, Inc. v. Thunder Craft Boats, Inc., 109 S. Ct. 971, 981-85 (1989). This decision concerned patent preemption, but the Court's logic would extend to preemption of state laws that afford copyright protection to works of authorship.

I17. See supra note 114 .

118. Compco, 376 U.S. at 237.

119. See Goldstein, 412 U.S. at 558-60. 
altogether, when it rejected the argument that the federal patent scheme preempted state trade secret protection of an industrial process-subject matter not only within Congress' constitutional intellectual property power, but within the purview of the patent statute as well. The Court found that rather than conflicting with federal patent policy, the state law furthered the same interests. ${ }^{120}$

Most recently, in Bonito Boats, Inc. v. Thunder Craft Boats, Inc., ${ }^{121}$ the Court appeared to waver between a preemption analysis based solely on the relationship between the state law and the federal statute, and a broader preemption analysis derived from the Patent-Copyright Clause. In Bonito Boats, the Court held that federal patent policies preempted a state statute prohibiting unauthorized reproductions of boat hulls by means of a direct molding process. ${ }^{122}$ The so-called "plug mold" statute focused on a particularly parasitic form of copying that yields an exact copy of the original hoat hull without the addition of any independent features by the copier. This aspect of the statute arguably complemented, rather than conflicted with, federal patent policy, for it protected the first producer's investment in boat hull design while permitting competition in all but the most blatant knock-off versions of the design. ${ }^{123}$ On the other hand, the statute concerned the act of copying per se; it did not purport to prohibit copying as an incident of remedying a different kind of proscribed conduct, such as deceptive advertising or breach of a trust relationship. ${ }^{124}$ As a result, the state law created something of a shadow patent, albeit of shrunken dimensions.

The Supreme Court found the state statute to fall squarely within the purview of the federal patent laws; it concerned subject matter regulable by patent, and supplied a patent-like remedy. The Court emphasized the

backdrop of free competition in the exploitation of unpatented designs and innovations. The novelty and nonobviousness requirements of patentability embody a congressional understanding, implicit in the Patent Clause itself, that free exploitation of ideas will be the rule, to which the protection of a federal patent is the exception. ... [T] must determine not only what is protected, but also what is free for all to use. ${ }^{125}$

120. See Kewanee Oil Co. v. Bicron Corp., 416 U.S. 470, 484 (1974) (process for growing artificial crystals).

121. 109 S. Ct. 971 (1989).

122. See id. at 974.

123. See John S. Wiley, Jr., Bonito Boats: Uninformed but Mandatory Innovation Policy, 1989 Sup. Ct. Rev. 283, 283-84.

124. See Fla. Stat. $\S 559.94$ (1987). See generally Shipley, supra note 76 , at 392-94 (suggesting that validity of state "plug molding" statutes may be undermined by questionable distinction made by states between "direct mold" copying, which is prohibited, and other sophisticated methods of copying, which are exempted from restriction by Congress).

125. Bonito Boats, $109 \mathrm{~S}$. Ct. at $977-78$. 
This last statement echoes Professor Gorman's argument regarding the interpretation of the copyright statute's exclusion of facts, ${ }^{126}$ but the Court appears to have elevated the principle to constitutional heights.

Does the public domain policy that Bonito Boats found implicit in the Patent-Copyright Clause preempt all state laws prohibiting copying of subject matter within the purview of the clause? Does it matter if the state law addresses conduct beyond copying? In its Sears-Compco decisions, the Court held preempted state unfair competition laws protecting lamp designs. ${ }^{127}$ Although the relief these laws provided included prohibitions on copying, the wrong complained of was not copying per se, but consumer confusion about the source of the copied goods. Were the Court returning in Bonito to the broader constitutional implications of Sears-Compco, one would expect the Court to focus on the result, rather than the rationale, of the state law. However, despite its resounding reaffirmation of federal public domain policy, Bonito Boats went on to distingnish nonpreempted state claims involving intellectual property, including unfair competition claims. For the Court, the "general concern [of unfair competition claims] is with protecting consumers from confusion as to source. While that concern may result in the creation of 'quasi-property rights' in communicative symbols, the focus is on the protection of consumers, not the protection of producers as an incentive to product innovation."128

This statement is surprising. In an opinion whose general tenor appears vigorously to reaffirm Sears-Compco, this statement would permit state anticopying remedies in precisely the situation disallowed by the 1964 decisions. If one takes this statement at face value, it would appear that a state anticopying remedy will survive Supremacy Clause preemption analysis, so long as there is some "plus" element, some conduct other than copying that the state law purports to regulate. In this case, preemption analysis may become entirely formalistic. Moreover, the Court's mention of "quasi property rights" evokes INS, a decision that forbade copying, even without a "plus" element of source confusion. ${ }^{129}$ In light of Bonito Boats, a preemption analysis that looks to the result, rather than the purpose, of the state law claim may eliminate too broad a range of state regulation.

Application of these principles of preemption analysis to state misappropriation claims against copying of information yields several possible results. First, claims presenting a "plus" element to the complaint of copying may well survive preemption, at least under Bonito Boats. This could be particularly true of misappropriation claims clothed in the garb of illicit access (acquiring data by breaking computer security

126. See Gorman, supra note 86 , at 604 .

127. See Sears, Roebuck \& Co. v. Stiffel Co., 376 U.S. 225, 231-32 (1964); Compco Corp. v. Day-Brite Lighting, lnc., 376 U.S. 234, 237-38 (1964).

128. Bonito Boats, 109 S. Ct. at 981 .

129. See supra text accompanying notes $77-85$. 
codes), or draped in the trappings of source confusion (nonattribution of the sources from which the data was copied). Second, unadorned anticopying claims might well be preempted. However, one might contend that there is no statutory or Patent-Copyright Clause preemption of state protection of facts at all, because the Supreme Court in Feist declared facts not to be the "Writings" of "Authors."130 If facts are not the "Writings" of "Authors," they fall outside the Patent-Copyright Clause, and, absent some other theory of preemption, remain within the power of the states to regulate. The next section of this Article therefore examines additional bases of preemption.

\section{Commerce Clause and Sister-State Preemption}

The possible resilience of state law protection of information in the face of preemption under the copyright statute and Patent-Copyright Clause should not obscure a different kind of federalism problem. To this point, the discussion has concerned "vertical" federalism issuesthat is, whether state regulation in the intellectual property field conflicts with federal regulation of the same field. State protection of information poses both dormant commerce clause and "horizontal," or sister-state, federalism issues as well.

As the Supreme Court observed in Goldstein v. Califormia ${ }^{131}$ one must inquire whether "in actual operation, the exercise of the power to grant copyrights by some States will prejudice the interests of other States."132 In Goldstein, the Court determined that no constitutionally significant sister-state conflict existed, a conclusion strongly influenced by the Court's view that "a copyright granted by a particular State has effect only within its boundaries." 133 Whatever the accuracy of this assumption in 1973, and of its twin concept of state regulation of subject matter of "purely local importance," 134 it seems most implausible today, particularly in the domain of electronic databases. As a practical matter, if not all fifty states will protect information, or will not protect it in the same ways, one state's regulation may disrupt the national dissemination of information as well as interfere with another state's information protection policies.

For example, suppose that Ohio, by common law or by statute, protects databases against the extraction of information for commercial purposes, including creation of derivative compilations that do not directly compete with their source. Suppose further that New York, preferring free access to and competition in information, affords no such protection; and that California law affords a remedy only against sub-

130. See Feist Publications, Inc. v. Rural Tel. Serv. Co., 111 S. Ct. 1282, 1287-89 (1991).

131. 412 U.S. 546 (1973).

132. Id. at 558 .

133. Id.

134. Id. 
stantial verbatim copying to create a directly competing compilation. Now assume that a California database producer brings a claim in Ohio against a New York defendant who accessed plaintiff's work in New York and there compiled a directory drawn entirely from information contained in plaintiff's database. Defendant's directory is differently organized and is aimed at a different clientele than plaintiff's. Defendant has sold copies of its directory in Ohio. ${ }^{135}$ What kinds of horizontal federalism problems does the Ohio suit pose?

If Ohio declines to apply its own law to this controversy, sisterstate sovereignty will be respected. However, the forum may well apply its own law, either by "homing instinct" reflex, or after some kind of conflicts inquiry. ${ }^{136}$ Application of Ohio's protective law would clash both with New York's free-copying policy and with California's limited scope of protection. The Ohio court might nonetheless attempt to avoid offense to these states (and to other states whose policies differ from Ohio's) by restricting the remedy to Ohio acts. Thus, any injunction would apply only to Ohio distribution of the directory, and damages would be awarded only for copies sold in Ohio.

But even this limited application of Ohio law may as a practical matter have extraterritorial implications compromising both sister-state sovereignty and national commerce. Defendant's directory travels in interstate commerce; keeping it out of Ohio may be no easy task. The problem becomes even more acute if defendant's directory is not a hardcopy document, but is itself a database, furnished to users through interstate transmission of data by wire, radio, or satellite signal. Ohio cannot erect boundaries impermeable to such signals. An Ohio injunction therefore becomes problematic. The injunction poses the potential for broad interstate effect: keeping phone or radio or satellite signals out of Ohio entails denial of access to all within the signal's reach. The extrusive character of the remedy in turn puts pressure on a

135. This example is inspired by the facts of Vault Corp. v. Quaid Software Ltd., 847 F.2d 255, 256-58 (5th Cir. 1988), in which a California software producer sold programs packaged with a "shrink-wrap license" that purported to prohibit purchasers from copying or decompiling the program. Defendant, a Canadian corporation, acquired plaintiff's software in Canada, and there decompiled it to generate a competing program. Some copies of defendant's program were sold in Louisiana. Plaintiff sued in Louisiana, alleging a violation of Louisiana's shrink-wrap license statute. The court held the statute preempted by the federal Copyright Act. See id. at 269-70.

136. In this case, the pre-interest analysis lex loci delicti rule would support application of Ohio law, since copies were sold in Ohio. Interest analysis might also lead to application of forum law, if only because interest analysis often indicates lex fori. See, e.g., Eugene F. Scoles \& Peter Hay, Conflict of Laws 16-27 (1984); Herma Hill Kay, Theory Into Practice: Choice of Law in the Courts, 34 Mercer L. Rev. 521, 587-88 (1983). In Vault Corp. v. Quaid Software Ltd., 655 F. Supp. 750 (E.D. La. 1987), aff'd, 847 F.2d 255 (5th Gir. 1988), the district court, after performing a perfunctory choice of law inquiry, applied Louisiana law (and later held it federally preempted), despite the slim, at best, contacts between the state, the parties, and the bulk of sales. See l'ault Corp., 655 F. Supp. at 757. 
court either to decline to recognize the Ohio law claim, ${ }^{137}$ to hold the Ohio law federally preempted under the Commerce Clause, ${ }^{138}$ or to hold it an impermissible encroachment on sister-state interests. ${ }^{139}$

The analysis in Part II has shown that state law regulation of the informational content of fact-based works, if not clearly impermissible under present federal preemption doctrines, is at least undesirable. If compiled information is to be protected, it would best be by means of federal law. Since Feist has now eliminated copyright protection for the "facts" themselves, inquiry into the power of Congress to pass a federal misappropriation statute to respond to problems posed by the exploitation of informational works is particularly pressing. The Court's enunciation of a constitutional bar to copyright in facts, however, constrains and may too greatly compromise Congress' authority to act effectively.

\section{Ill. Congress' Constitutional Authortty to Enact a Statute Protecting Against Misappropriation of Compiled INFORMATION}

ln Feist, the Supreme Court referred on several occasions to the Trade-Mark Cases, ${ }^{140}$ in which the Court invalidated trademarks legislation passed under the Patent-Copyright Clause on the ground that trademarks, as neither "Writings" nor "Discoveries," were not within

137. Cf. RCA Mfg. Co. v. Whiteman, 114 F.2d 86, 89-90 (2d Cir.), cert. denied, 311 U.S. 712 (1940). In this case, Judge Learned Hand declined to recognize asserted equitable servitude arising out of "not for broadcast" labels on sound recordings. He acknowledged that the Supreme Court of Pennsylvania, in Waring v. WDAS Broadcasting Station, 194 A. 631 (Pa. 1937), had reached a contrary decision, and that broadcast of the records into Pennsylvania would thus be a tort in that state; but he declined to enter an injunction for the sole benefit of Pennsylvania, when all surrounding territories would not uphold the servitude:

[E]ven if it be mechanically possible to prevent any broadcasting through the angle which the state of Pennsylvania subtends at the transmission station, that would shut out points both in front of, and beyond, Pennsylvania. We must therefore choose between denying any injunction whatever-since in our judgment the act is unlawful only in Pennsylvania-or enjoining [defendant] from broadcasting throughout the Union and in Canada in order to prevent a tort in Pennsylvania alone.

$R C A M f g ., 114$ F.2d at 89-90.

138. Cf. Capital Cities Cable, Inc. v. Crisp, 467 U.S. 691, 698-711 (1984) (holding that Commerce Clause-derived FCC Act preempted Oklahoma's prohibition on certain kinds of television advertising; since broadcast signals came from out-of-state, Oklahoma's law necessarily affected all states receiving broadcast signal). To the extent that state regnlation impacts on information communicated by cable or satellite, the state law may be preempted under the Federal Communications Act, 47 U.S.C. $\S \S 151-613$ (1988).

139. Cf. Goldstein v. California, 412 U.S. 546, 558-59 (1973) (recognizing state copyright protection may result in conflict between respective interests of sister states, but finding no significantly prejudicial conflict exists where state outlaws "piracy" of sound recordings).

140. 100 U.S. 82 (1879). 
the subject matter that Congress had power to protect under that clause. The Trade-Mark Cases Court also indicated that the trademarks legislation might have passed muster under the Commerce Clause had the law been limited to regulation of trademarks in interstate or international commerce. ${ }^{141}$ Paul Goldstein has remarked that Feist's references to the Trade-Mark Cases suggest that the Court endorses the Commerce Clause as the basis for an extension of federal information protection. ${ }^{142}$ But Feist's claim that its standard of originality is "constitutionally mandated" may impede enactment of a federal law protecting unoriginal compiled information under the Commerce Clause. ${ }^{143}$

This Part therefore will explore several constitutional issues. The first concerns the relationship between the Patent-Copyright Clause and the Commerce Clause. If, as the Supreme Court has stated, the Patent-Copyright Clause limits Congress' power to protect information, may Congress overcome that limitation by resort to the Commerce Clause's more general source of constitutional power to legislate? If the Patent-Copyright Clause does limit Congress' legislative authority under the Commerce Clause, may Congress nonetheless legislate some form of anticopying protection under the latter clause, provided the terms of protection of works of information are substantially different from those of a copyright regime?

A different inquiry returns to the Patent-Copyright Clause. The Supreme Court's interpretation of the clause in Feist adds to the constitutional text a requirement of creativity. But is the Supreme Court's interpretation necessarily binding? Putting aside the question of whether the Court's repeated pronouncements were dictum, one might contend that Congress has special competence to interpret the meaning of the terms of the Patent-Copyright Clause, or at least to find as a matter of "legislative fact" that certain productions, including useful compilations, constitute the "Writings" of "Authors."

Finally, would a statute protecting compiled information survive First Amendment scrutiny? How should such a statute be drafted in order both to supply needed incentives to information gatherers, and to protect the public interest in access to information?

141. See id. at 96.

142. See Goldstein, supra note 4 , at 119.

143. Congress might also protect information by amending the Copyright Act to make clear that the statute does not preempt state protections for information. Cf. McCarran-Ferguson Act, 15 U.S.C. $\$ \$ 1011-15$ (1988), discussed in Prudential Ins. Co. v. Benjamin, 328 U.S. 408, 429-30 (1946) (despite Supreme Court's prior holding that insurance was within Congress' commerce power, Congress declared insurance a matter for state regulation). By deliberately not occupying the field, Congress may leave room for state regulation. However, this approach does not resolve the sister-state federalism problems discussed above. See supra notes 131-139 and accompanying text. 


\section{A. Patent-Copyright Clause Limitations on Congress' Authority to Legislate Under the Commerce Clause}

The prospect of federal legislation to protect compiled information prompts inquiry into a possible conflict within Article I, Section 8 of the Constitution. That text authorizes Congress both to "promote the Progress of Science and Useful Arts, by securing for limited Times to Authors and Inventors the exclusive Right to their respective Writings and Discoveries,"144 and to "regulate Commerce ... among the several States." 145 Because the grant of a monopoly to authors and inventors implicates interstate commerce, one may assert that copyrights and patents could be legislated under the Commerce Clause as well as under the more specific grant of authority. ${ }^{146}$ However, the Patent-Copyright Clause includes directions and limitations on Congress' authority that the Commerce Clause lacks. For example, the patent and copyright monopolies may not be perpetual; they must be for "limited Times." 147 And, under the Supreme Court's Feist approach, the copyright monopoly may be granted only to original, creative writings. May Congress dispense with the constraints of the Patent-Copyright Clause by legislating under the broader Commerce Clause grant of power?

Although the Supreme Court has not ruled on the question of a conflict between the Patent-Copyright Clause and the Commerce Clause, ${ }^{148}$ it has confronted a similar question regarding the Bankruptcy Clause. The Bankruptcy Clause empowers Congress to establish "uniform Laws on the subject of Bankruptcies throughout the

144. U.S. Const. art. I, § 8, cl. 8.

145. Id. cl. 3.

146. See, e.g., 1 Nimmer on Copyright, supra note $7, \S 1.09$, at 1-60 to 1-62 (discussing effect of copyright industries on U.S. commerce); cf. Authors League of America, Inc. v. Oman, 790 F.2d 220, 224 (2d Cir. 1986) (manufacturing clause of 1976 Copyright Act is justified both under patent-copyright power and under Commerce Clause).

The Semiconductor Chip Protection Act, 17 U.S.C. $\$$ 900-914 (1988), was enacted under both the Patent-Copyright Clause and the Commerce Clause. See Senate Explanatory Memorandum, 130 Cong. Rec. S12,916 (daily ed. Oct. 3, 1984), reprinted in David Ladd et al., Protection for Semiconductor Chip Masks in the United States 59, 65-66 (1986); see also sources cited in Kenneth J. Burchfiel, The Constitutional Intellectual Property Power: Progress of Useful Arts and the Legal Protection of Semiconductor Technology, 28 Santa Clara L. Rev. 473, 503 n.203 (1988) (indicating that while congressional authority is based primarily on the Copyright Clause, commerce power is also relied upon). Section 131 of the Plant Variety Protection Act, 7 U.S.C. \$§ 2321-2583 (1988), declares that the statute is enacted pursuant to both the patent-copyright and the commerce powers. See also H.R. Rep. No. 1605, 91st Cong., 2d Sess. 12 (1970) (citing commerce and patent powers as constitutional basis of the Plant Variety Act, which sought to encourage development of novel varieties of plants by providing for issuance of "certificates of plant variety protection").

147. U.S. Const. art. I, $\S 8, \mathrm{cl} .8$.

148. Cf. Twentieth Century Music Corp. v. Aiken, 422 U.S. 151, 156 (1975) (declaring constitutional bar to perpetual copyright). 
United States."149 In Railway Labor Executives'Ass'n v. Gibbons, ${ }^{150}$ a controversy involving a bankruptcy law enacted for the benefit of the employees of the defunct Rock Island Railroad, the Court determined that Congress would not have power under the Commerce Clause to enact nonuniform bankruptcy laws. Justice Rehnquist declared: "If we were to hold that Congress had power to enact nonuniform bankruptcy laws pursuant to the Commerce Clause, we would eradicate from the Constitution a limitation on the power of Congress to enact bankruptcy laws." 151 Under this approach, one could contend that a law protecting compiled information under the Commerce Clause would similarly be invalidated as an attempt to elude a substantive limitation on Congress' power to grant copyrights.

The premise of Justice Rehnquist's approach is that the more specific clauses of the Constitution limit the more general. One might on the contrary argue that the more specific clauses are simply illustrations of the more general powers. ${ }^{152}$ Moreover, as Professor Baird has written, criticizing this aspect of the Railway Labor reasoning, "one is not compelled to construe words of the grant as both a grant and a limitation of power." 153 While Professor Baird's argument has syntactic appeal, the Supreme Court may already have foreclosed it in the PatentCopyright Clause context, where the Court described that clause as "both a grant of power and a limitation."154

Assuming that the more specific clause does limit the more general one, Congress does not have power to override Patent-Copyright Clause limitations by creating under the Commerce Clause a form of protection of compiled information coextensive with copyright protection. However, Congress might have power to enact a misappropriation statute under the Commerce Clause if the statute set forth a

149. U.S. Const. art. I, § 8, cl. 4.

150. 455 U.S. 457 (1982).

151. Id. at $468-69$.

152. See Douglas G. Baird, Bankruptcy Procedure and State-Created Rights: The Lessons of Gibbons and Marathon, 1982 Sup. Ct. Rev. 25, 30 "'Although the canon of interpretation that clauses of a constitution should not be redundant is useful, it is not absolute. The Framers might well have accepted some redundancy as a cost of being clear.").

153. Id.; accord McCulloch v. Maryland, 17 U.S. (4 Wheat.) 316, 416 (1819) (rejecting principle of construction that constitutional grants of authority are also limitations).

154. See Graham v. John Deere Co., 383 U.S. 1, 5 (1965) (hence, for example, Congress' authority to grant patents "is limited to the promotion of advances in the 'useful arts' "); see also William Winslow Crosskey, Politics and the Constitution in the History of the United States 486 (1953) (detailing importance to the Framers of "limited Times" proviso of Patent-Copyright Clause, and concluding that "this power [the copyright power] of Congress was enumerated in the Constitution, for the purpose of expressing its limitations"); see generally Burchfiel, supra note 146, at 507-10 (discussing other sources of limitation on Article 1, section 8 grants of powers to Congress within Article 1 and in the remainder of the Constitution). 
scheme of protection qualitatively different from a copyright regime. Trademarks supply a pertinent analogy. While the Supreme Court in the Trade-Mark Cases ${ }^{155}$ rejected Patent-Copyright Clause protection for trademarks, Congress has since legislated under the Commerce Clause. ${ }^{156}$ The Lanham Trademarks Act ${ }^{157}$ protects distinctive words and symbols against copying, but only to the extent that the copying or imitation is likely to cause confusion as to the source or sponsorship of the goods or services, or constitutes a false representation. ${ }^{158}$ In other words, the federal trademarks law affords protection not against copying per se, but against falsehoods in the marketplace. As a result, the protection afforded under the Lanham Act is not substantively equivalent to copyright or patent protection. One may therefore contend that the Commerce Clause-dependent Lanham Act does not run afoul of Patent-Copyright Clause limitations, for the federal trademarks law governs conduct different from that at issue in patent and copyright laws. 159

By the same token, one may argue that a Commerce Clause-derived statute barring misappropriation of compiled information would not conflict with the Patent-Copyright Clause as long as the protective law departs in significant ways from the copyright model. Appropriate and meaningful departures might be made with respect to duration of

155. 100 U.S. 82 (1879).

156. See 15 U.S.C. $\$ 1051$ (a) (1988) (registration of trademarks "used in commerce"); id. § 1127 ("The word 'commerce' means all commerce which may lawfully be regulated by Congress.").

157. 1d. §§ 1051-72, 1091-96, 1111-27.

158. See id. $\S \S 1114,1125(a)$.

159. See, e.g., Ferrari s.p.a. v. Roberts, 20 U.S.P.Q.2d (BNA) 1001, 1006-07 (6th Cir. 1991) (protection of trade dress and product design of unpatented articles under the Lanham Federal Trademarks Act does not conflict with design patent protection because purpose and scope of protection of trademark and patent laws differ); In re Mogen David Wine Corp., 372 F.2d 539, 543 (C.C.P.A. 1967) (Smith, J., concurring) (same, regarding federal trademark registration of distinctive ornamental designs).

But see section 110 of the Amateur Sports Act of 1978, 36 U.S.C. $\$ 380$ (1988) (statute granting United States Olympic Committee exclusive rights in term "Olympic" and interlocking circles symbol, even in the absence of likelihood of confusion); San Francisco Arts \& Athletics, Inc. v. United States Olympic Comm., 483 U.S. 522, 535-41 (1987) (upholding "Olympic" term and symbol statute despite First Amendment challenge). The Supreme Court did not address the question whether the statute might be vulnerable as an impermissible patent- or copyright-like grant of exclusive rights. Rather, the Court stated that U.S. Olympic Committee investment in making the olympic term and symbol a distinguishing mark entitled it to a "limited property right ... [that] falls within the scope of trademark law protections." Id. at 534-35. Arguably, the Court's citation of International News Serv. v. Associated Press, 248 U.S. 215, 239 (1918), for the proposition "that when a word acquires value 'as the result of organization and the expenditure of labor, skill, and money' by an entity, tbat entity constitutionally may obtain a limited property right in tbe word," San Francisco Arts, 483 U.S. at 532, evidences a confusion of patent- and copyright-like property with trademark interests. However, this confusion suggests the Court did not perceive an intra-Article I impediment to legislating a property right in gross under the Commerce Clause. 
protection and, more significantly, with respect to scope of protection. Copyright protection lasts for the life of the author plus fifty years, or in the case of a work made for hire (as many information compilations are likely to be), for at least seventy-five years from creation of the work. ${ }^{160}$ The duration of statutory protection of compiled information might be made considerably shorter-for example, ten years from dissemination. ${ }^{161}$ The scope of protection might be limited by imposition of compulsory licenses. ${ }^{162}$ An elaborated system of compulsory licenses heightens the dissimilarities between the proposed compiled information protection statute and the copyright model of "exclusive Right[s]." In its most basic form, a federal misappropriation statute would accord no exclusive right of control over the compiled information, ${ }^{163}$ but would merely guarantee the information gatherer the right to be paid for third-party use of the information. Distinguished in this way from conventional copyright legislation, a federal misappropriation statute might avoid a clash between the provisions of Article 1, Section 8.164

Another approach to a federal misappropriation statute would distingnish rights arising under it from copyright by affording more, rather than less, protection. For example, if the statute protected not only against copying information, but against remanipulating information into a different arrangement or selection, one might emphasize the distinction in acts rendered illicit by the copyright law and by a special

160. Protection expires one hundred years after creation or 75 years after publication, whichever occurs first. See 17 U.S.C. $§ 302$ (1988).

161. The Nordic countries have enacted special extra-copyright "catalogue protection" statutes granting sui generis anticopying protection to unoriginal compilations. The protection endures for ten years. See Creation and Commercial Value, supra note 6, at 1924 n.223; W.G. Gunnar Karnell, The Nordic Catalogue Rule, in Protecting Works of Fact 67 (Egbert J. Dommering \& P. Bernt Hugenholtz eds., 1991). A directive recently proposed by the European Communities follows a similar approach. See infra text accompanying notes 212-218.

162. See Creation and Commercial Value, supra note 6, at 1924-36, for an extended discussion of compulsory and collective licensing of information compilations.

163. At least, exclusive control would not be guaranteed after the compiled information is made public. Arguably, undisclosed information is already subject to the compiler's federal common law property right. See Carpenter v. United States, 484 U.S. 19, 25-27 (1987); Samuelson, supra note 5, at 366-68; see also Creation and Commercial Value, supra note 6 , at 1928 n.232 (proposing that compulsory licenses apply only to publicly disclosed information).

Carpenter also suggests that Congress could devise a federal misappropriation statute under the Commerce Clause to protect against unlicensed copying from undisclosed, or partially disclosed, databases. Arguably, this claim is not substantively distinct from copyright, because copyright covers both disseminated and undisseminated works. Nonetheless, the undisclosed character of the database might present an element warranting special federal coverage. However, such a federal statute also presents the disadvantage of encouraging nondisclosure of information.

164. Cf. Mazer v. Stein, 347 U.S. 201, 217-19 (1954) (upholding copyright protection for ornamental designs incorporated in useful objects despite availability of design patent protection; no conflict between two modes of protection because scope of copyright protection is more limited than scope of patent protection). 
compilations statute legislated under the Commerce Clause. After Feist, there can be no copyright liability for copying information stripped of the compiler's "original" contributions. Under a compilations statute protecting "sweat," by contrast, liability would arise from copying the compiled information, whether or not the copied elements of the information displayed creative originality in selection or arrangement. The statute thus would apply to conduct not covered by the copyright law. If there is no overlap in regulated conduct, perhaps the two regimes would not clash, and there would be no intra-Article I conflict. However, under the constitutional free-riding principle announced in Feist, if copyright fails to reach the conduct targeted by the hypothetical compilations statute, that may be the result of inherent limitations the Court has perceived to be imposed on the copyright power by the constitutional originality standard. In that case, it seems doubtful that Congress could override these limitations by resort to a different legislating label. ${ }^{165}$

There is an additional objection to both misappropriation statutes sketched above: while both may differ in degree from copyright protection, they do not differ in kind. Unlike the trademark statute, whose target is not copying per se, but the impact of the copying on consumer understanding, both misappropriation statutes described here are essentially anticopying statutes, although one offers less exclusivity of coverage and the other offers more. With respect to the less protective misappropriation statute, even though the information proprietor may be foreclosed from forbidding copying, the act of unauthorized copying still triggers liability. Indeed, despite the variety of compulsory licenses included in the current copyright act, the statute denominates the rights conferred on authors as "exclusive rights."166 With respect to the more protective misappropriation statute, the right to prevent the

165. Nonetheless, even when the copyright statute clearly withholds copyright protection from certain classes of works, this denial of coverage does not inevitably preclude creation of some kind of property right in the work pursuant to another source of federal authority. Cf. International News Serv. v. Associated Press, 248 U.S. 215, 236 (I918) (federal common law "quasi-property" right in news information, despite exclusion from copyright protection); Harold Edgar \& Benno C. Schmidt, Jr., CurtissWright Comes Home: Executive Power and National Security Secrecy, 2 I Harv. C.R.C.L. L. Rev. 349, 404 (1986) (although section 105 of the 1976 Copyright Act precludes copyright in works of the federal government, courts have found that government information may nonetheless be a "thing of value" whose unauthorized taking can constitute a crime under I8 U.S.C. § 64I (I988)).

166. See 17 U.S.C. $\$ 106$ (1988) (rights accorded termed "exclusive"); id. § 111 (cable compulsory license termed a "limitation on exclusive rights"); id. $\$ 115$ (same about compulsory license to make sound recordings of certain musical compositions); id. $\$ 116$ (same about compulsory license for certain jukebox performances); id. § 501 (infringement defined as violation of "exclusive rights . . . as provided by [various dispositions including the compulsory licenses]"); see also T.B. Harms Co. v. Jem Records, Inc., 655 F. Supp. 1575, 1580-81 (D.N.J. 1987) (reconciling compulsory licenses with exclusive rights). 
excerpting or reorganization of works is also a right under copyright: the right to prepare derivative works. ${ }^{167}$ Thus, the general conduct at issue is conduct regulated by copyright, even though the conduct as applied to the subject matter of unoriginal components of compilations is not, after Feist. ${ }^{168}$

\section{B. Congress' Authority to Implement the Terms of the Patent-Copyright Clause}

The prior discussion sought to reconcile a Commerce Clausebased statute barring misappropriation of compiled information with the limitations imposed by the Patent-Copyright Clause. An alternative approach would reconsider those limitations. The Constitution authorizes Congress to grant copyrights to "Authors" for their "Writings." The Feist decision construes both terms to demand creativity. Citing the Trade-Mark Cases, in which the Court had described the "writings to be protected" as "the fruits of intellectual labor," the Feist Court declared that a "writing" must manifest "a modicum of creativity."169 Citing Burrow-Giles Lithographic Co. v. Sarony, ${ }^{170}$ in which the Court had defined an "author" as "he to whom anything owes its origin; originator; maker," the Feist Court found authority for requiring "the creative component of originality." 171

There is room for argument that the Feist court misapplied prior Supreme Court interpretations of the Patent-Copyright Clause. For example, the "intellectual labor" required of a "Writing" in the TradeMark Cases might be satisfied by the identification and assembly of information into a compilation, without regard to the subjectivity of the selection or arrangement. The "Author" at the "origin" of a work, as contemplated in Burrow-Giles, could include the maker of a compilation of information, without regard to the creativity of the compilation. Similarly, neither of these decisions addressed the scope of copyright protection. Thus, they do not support a constitutional limitation of a copyright claim to the copying of the author's "original" contributions.

167. See 17 U.S.C. $\$ 106(2)$ (1988).

168. One kind of statute that might differ sufficiently from a copyright regime would focus on contract remedies. Congress could enact a federal shrink-wrap license validating the obligation of purchasers of copies of information compilations (e.g., databases distributed on CD ROM) to refrain from copying the compilation for any purpose other than the purposes permitted by the compiler. Creation or distribution of copies for any other purpose would give rise to a federal breach of contract claim. While persons who obtain the compilation from purchasers and who create copies of the compilation are not in privity with the information provider and therefore may not be directly liable for breach of contract, the statute might further charge these persons with notice of the contractual limitation and therefore render them liable as well. A disadvantage of this kind of statute, besides its complexity, is the incentive it presents to burden the dissemination of information with conditions.

169. Feist Publications, lnc. v. Rural Tel. Serv. Co., 111 S. Ct. 1282, 1288 (1991)

(citing The Trade-Mark Cases, 100 U.S. 82, 94 (1879)).

170. 111 U.S. 53 (1884).

171. Feist, 111 S. Ct. at 1288 (citing Burrows, 111 U.S. at 57-58). 
Indeed, contemporary case law indicates no such perceived limitation on acts constituting infringement: courts had found violations not only when information was copied "wholesale" (so that whatever "original" contribution that subsisted may also have been copied), but also when subsets of information were extracted from plaintiff's work. ${ }^{172}$

However, I will pursue a different argument: whatever the Supreme Court's prior interpretations of the Patent-Copyright Clause, Congress may nonetheless supply the content of that clause. Even if Congress cannot claim ultimate authority to interpret those portions of the Constitution that bear neither on separation of powers nor on individual rights, ${ }^{173}$ Congress should enjoy substantial discretion in implementing its constitutional prerogative to "promote the Progress of Science." 174 Congress' determination of what endeavors constitute the "Writings" of "Authors" should be viewed as an exercise of fact-finding by the body most competent to evaluate the efficacy of the means chosen to promote the constitutional goal. ${ }^{175}$ Supreme Court review of these kinds of congressional findings therefore should be extremely deferential. ${ }^{176}$

172. See, e.g., Sampson \& Murdock Co. v. Seaver-Radford Co., 140 F. 539, 540, 545 (1st Cir. 1905) (infringement found when 12\% of listings in plaintiff's directory were copied); see also Dun v. Lumbermen's Credit Ass'n, 209 U.S. 20, 23-24 (1908) (infringement found from partial copying of directory listings but because defendant had invested much independent labor, plaintiff's remedy was limited to damages).

173. Compare Jesse H. Choper, Judicial Review and the National Political Process: A Functional Reconsideration of the Role of the Supreme Court 60-70 (1980) (arguing that judicial review should focus primarily on questions implicating individual rights) with Henry P. Monaghan, Book Review, 94 Harv. L. Rev. 296, 302-07 (1980) (criticizing Choper's elimination of some separation of powers questions from scope of judicial review).

174. U.S. Const. art. $1, \S 8, \mathrm{cl} .8$; accord Sony Corp. v. Universal City Studios, 464 U.S. 417, 429 (1984) ("As the text of the Constitution makes plain, it is Congress that has been assigued the task of defining the scope of the limited monopoly . . . in order to give the public appropriate access . ... "); cf. South Dakota v. Dole, 483 U.S. 203, 207 (1987) (in exercise of Congress' Article I, Section 8 spending power, Supreme Court defers to Congress' determination of what constitutes "the general welfare").

In Feist, the Court interpreted the Copyright statute to exclude compilations lacking original selection or arrangement; the statutory and constitutional criteria were thus coextensive. As a result, the Court did not find that in this instance Congress lacked or had exceeded its discretion under the Patent-Copyright Clause. However, the Court's discussion imposes constitutional limits that would constrain Congress were it disposed toward a more generous construction of originality than that which the Court attributed to it. See infra note 190 and accompanying text.

175. Cf. Archibald Cox, The Role of Congress in Constitutional Determinations, 40 U. Cin. L. Rev. 199, 207-11, 224-26 (1971) (arguing Congress has authority to determine as legislative fact what activities constitute "Commerce"); Henry P. Monaghan, Marbury and the Administrative State, 83 Colum. L. Rev. 1, 34 n.194 (1983) (noting "large role given Congress where the decisive issue turns not on language but on 'legislative facts" ").

176. Cf. Katzenbach v. McClung, 379 U.S. 294, 303-05 (1964) (civil rights statute's regulation of restaurant serving largely in-state clientele comes within congressional commerce power). See generally Laurence H. Tribe, American Constitutional Law 
The Feist Court's textual exegesis of the Patent-Copyright Clause contrasts with its general approach to Article I grants of legislative power. As Professor Tribe has observed: "The Supreme Court has in recent years largely abandoned any effort to articulate and enforce internal limits on congressional power-limits inherent in the grants of power themselves. Rather the Court has been concerned chiefly with developing external limits" such as constraints deriving from separation of powers, federalism, and individual rights concerns. ${ }^{177}$ In the context of the Patent-Copyright Clause, the Court had earlier announced considerable deference to congressional definition of the content and scope of the limited monopoly, stating, for example, " $[t]$ he direction of Art[icle] I is that Congress shall have the power to promote the progress of science and the useful arts. When, as here, the Constitution is permissive, the sign of how far Congress has chosen to go can come only from Congress."178 Feist, however, suggests that the Constitution has become less "permissive" as to Congress' authority to determine the content of its power.

There is legislative precedent for expansive congressional interpretation of the key terms of the Patent-Copyright Clause. In the Plant Patent Act, ${ }^{179}$ Congress construed the clause's authorization to grant patents to "Inventors" for their "Discoveries" to cover the discovery and asexual propagation of "distinct and new" varieties of plants. While newly found plant varieties might well constitute "Discoveries," the legislation posed problems because the finder might not be considered an "Inventor." The finder would not have created the plant; he would simply have come upon it, and then have propagated it asexually. Congress was well aware of the constitutional issue of interpretation. ${ }^{180}$

310-11 (2d ed. 1988) (noting consistent Supreme Court deference to Congress' factual findings that local activities affect interstate commerce).

177. Tribe, supra note 176, at 297; accord Paul Brest, The Conscientious Legislator's Guide to Constitutional Interpretation, 27 Stan. L. Rev. 585, 592 (1975) ("Even accounting for motives, few exercises of the article I powers are constitutionally controversial.").

178. Deepsouth Packing Co. v. Laitram Corp., 406 U.S. 518, 530 (1972) (upholding patent statute's grant of a lower level of protection than plaintiff contended was constitutionally allowable); accord Sony Corp., 464 U.S. at 429-31.

179. 35 U.S.C. $\S 161$ (1988) (amended 1954).

180. The Senate Committee report states: "There can be no doubt that the grant of plant patents constitutes a promotion of the 'progress of science and useful arts' within the meaning of the constitutional provision. The only question is, Is the new variety a discovery and is the originator or discoverer an inventor?" $S$. Rep. No. 315, 71st Cong., 2d Sess. 6 (1930).

A similar problem is posed by the potential shift of the U.S. patent system from its current "first-to-invent" criterion to the "first-to-file" criterion applied in most other countries. If the "lnventor" in the constitutional sense must be the first creator, then a first-to-file system might violate the constitutional standard. If the term "Inventor" is open to broader congressional interpretation, then Congress could define the inventor 
Congress supported its determination that the finder could be deemed an "Inventor" with two arguments, one historical, the other addressed to institutional competence. The meaning of the "Inventor" term current in the Framers' day, the Senate Report asserts, was synonymous with "discoverer."181 Interestingly, the Report drew further historical support for its contention that "Inventor" need not mean "creator" from legislative and judicial interpretation of the PatentCopyright Clause term "Author." The Senate Committee observed that the first Congress granted copyright to maps and charts as well as books, and that "[i]t might well be doubted whether map makers [and] chart makers . . . were "authors." "182 Over time, the Committee observed, Congress and the courts have given the term "author" a "broad meaning" that it "certainly do[es] not have in ordinary speech."183 Although the Committee did not make its contention explicit, it appears that the Committee believed that if one who finds and reports geographical or maritime facts (that is, a map maker or chart maker) can be called an "author," then one who finds and propagates plants can be called an "inventor." Thus, the Committee stated, "inventors' is certainly as elastic a word as 'authors.' "184 bluntly:

The Committee put the institutional competence argument more

It is not to be expected that the courts would place themselves in the position of impeding the progress of science and useful art of agriculture by holding to so narrow a definition of the word "inventor" as to find that the proposed legislation was undoubtedly beyond the power of the Congress. ${ }^{185}$

as one who both creates and files, thus making the shift to first-to-file consistent with the constitutional grant of authority.

181. Id. at 8.

I82. Id. at 9 .

183. Id.

I84. Id.

185. Id.; accord 35 U.S.C. $§$ I6I (1988) (amended I954). Congress expanded the Plant Patent Act to protect new plants developed by accident as well as those deliberately planned. See S. Rep. No. 1937, 83rd Cong., 2d Sess. 2 (1954), reprinted in I954 U.S.C.C.A.N. 398I, 3982. During consideration of this amendment, the Commerce Department submitted a letter contending that the amendment was inconsistent with the constitutional criterion of invention as interpreted by the Supreme Court. See S. Rep. No. 1937, supra, at 3-4, reprinted in 1954 U.S.C.C.A.N. at 3983-84. The Committee simply responded: "It was further stated that H.R. 5420 might [be] unconstitutional, but the committee is of the opinion that this type of legislation does have constitutional basis for its enactment." S. Rep. No. 1937, supra, at 2, reprinted in 1954 U.S.C.C.A.N. at 3981-82.

Burchfiel, supra note 146 , at $475,510-40$, argues that despite the Semiconductor Chip Protection Act's reliance on the copyright and commerce powers, the legislation is better characterized as a modified patent for mask designs and chips that fail to meet patent nonobviousness standards. Burchfiel contends that nonobviousness is not a constitutionally mandated standard of patentability, and therefore Congress had power under the patent component of Article I, section 8, clause 8 to enact the Chip Act. He 
Certain assumptions underlie this rather truculent expression of Congress' role in implementing the Patent-Copyright Clause. First, it is for Congress to determine what protections promote the progress of science (knowledge). Second, while the Court may ultimately determine what the constitutional language means, its review should defer to Congress' evaluation of what activities make one an "inventor" (or an "author") because it is by giving content to these terms that Congress effectuates the constitutional policy of promoting knowledge. In effect, Congress is better situated than is the Court not only to make the policy determination of what constitutes the progress of knowledge, but to judge what means best achieve that goal. ${ }^{186}$

Decisions as to what constitutes knowledge and how to achieve its progress seem particularly ill-adapted to the judicial branch. ${ }^{187} \mathrm{~A}$ judgment that, under the Constitution, a given work or class of works does not promote knowledge seems implausible as a matter of fact, and extravagant, if not overreaching, as a matter of technique. Even the Feist Court did not suggest that unoriginal compilations fail to promote knowledge; the Court's acknowledgment of these works' utility suggests the contrary. ${ }^{188}$ Rather than evaluating Congress' compliance with the constitutional goal, the Feist Court focused on the compatibility of a particular means (protecting the white pages) with the constitutional text. However, the Court's technique proves as radical as ruling that certain works do not promote knowledge. This is because the Court did not claim that Congress had itself selected this means; indeed, the Court had found that the copyright statute did not extend protection to the white pages. ${ }^{189}$ Instead, the Court stretched to reach the abstract constitutional issue; its determination in effect declares that had Congress sought to protect the white pages (or similarly noncreative productions) or should Congress so seek, the Constitution would not permit Congress to extend copyright protection to that subject matter. ${ }^{190}$

This was both unnecessary and inconsistent with the Supreme

further argues that judicial review should inquire only into the rational relationship between the legislation and the constitutional purpose of promoting the useful arts.

186. Cf. Cox, supra note 175, at 209-11 (discussing Congress' superior role as fact finder).

187. See Mitchell Bros. Film Group v. Cinema Adult Theater, 604 F.2d 852, 858-60 (5th Cir. 1979), cert. denied, 445 U.S. 917 (1980). But see Martinetti v. Maguire, 16 F. Cas. 920, 922-23 (No. 9173) (C.C. Cal. 1867) (denying copyright protection to stage production on grouud that, albeit not obscene, it failed to promote the progress of knowledge). (1991).

188. See Feist Publications, Inc. v. Rural Tel. Serv. Co., 111 S. Ct. 1282, 1297

189. See id. at 1295 .

190. Cf. Marci A. Hamilton, Justice O'Connor's Intellectual Property Opinions: Currents and Crosscurrents, Rutgers Women's Rts. L. Rep. (forthcoming Spring 1992) (manuscript at 14-15, on file with the Columbia Law Review) (Feist opinion excludes class of white pages directories from copyright protection). 
Court's past approach to Congress' definition of the intellectual property domain. ${ }^{191}$ Prior Supreme Court pronouncements pointed to considerable legislative discretion to select the means to achieve the progress of knowledge. For example, the Court had recognized in the patents context that "[w]ithin the limits of the constitutional grant, the Congress may, of course, implement the stated purpose of the Framers by selecting the policy which in its judgment best effectuates the constitutional aim." 192 In Feist, with neither specific congressional action, nor an extensive factual record (as neither side had briefed or argued the constitutional issue), the Court has interpreted the "limits of the constitutional grant" in such a way as to preclude Congress from implementing the constitutional aim by selecting an intellectual property policy that would include protection for information independent of creative compilation.

Feist's categorical approach to Congress' copyright power ignores the elasticity of the concept of original authorship in our copyright law. Over the 200 and more years since the first copyright statute, Congress has implemented the Framers' purpose by adopting increasingly expansive characterizations of the "Writings" of "Authors." Congress has interpreted its grant of power to embrace a variety of productions, from maps, ${ }^{193}$ to photographs, ${ }^{194}$ to sound recordings, ${ }^{195}$ to computer programs. ${ }^{196}$ It is not self-evident that any of these works are authorial creations. Indeed, legislators and commentators in many foreign countries consider that sound recordings are too mechanical in nature to be the works of authors, ${ }^{197}$ and express similar hesitations regarding pho-

191. Cf. Burchfiel, supra note 146 , at 533 (" $[\mathrm{C}]$ ontemporary constitutional theory provides no support for the suggestion that new and restrictive definitions of constitutional terms such as 'science,' 'author' or 'inventor' may be coined by the judiciary to limit congressional power under the intellectual property clause." (footnote omitted)). But see Walter J. Derenberg, The Meaning of "Writings" in the Copyright Clause of the Constitution, in 1 Studies on Copyright 43, 65 (Arthur Fisher Memorial ed., 1963) (despite tradition of judicial deference, there has been and should be judicial review of terms "Author" and "Writing" for conformity to basic principles of originality and creativity).

192. Graham v. John Deere Co., 383 U.S. 1, 6 (1965); accord Sony Corp. v. Universal City Studios, 464 U.S. 417, 431-32 (1984) (noting that it is the role of Congress, not the courts, to balance competing interests through copyright protection); Deepsouth Packing Co. v. Laitram Corp., 406 U.S. 518, 529-30 (1972) (refusing to use Patent-Copyright Clause as aid to construing Patent Act because "[w]hen, as here, the Constitution is permissive, the sign of how far Congress has chosen to go can come only from Congress").

193. See Act of May 31, 1790, ch. 15, 1 Stat. 124 (repealed 1802), reprinted in Copyright Enactments of the United States 1783-1906, at 22-24 (Thorvald Solberg ed., 1963) [hereinafter Copyright Enactments].

194. See Act of Mar. 3, 1865, ch. 126, § 1, 13 Stat. 540.

195. See Act of Oct. 15, 1971, 85 Stat. 391.

196. See Act of Dec. 12, 1980, ch. 38, § 211, 94 Stat. 3028.

197. See, e.g., Henri Desbois, Le Droit d'Auteur en France [Copyright in France] 
tographs. ${ }^{198}$ Similarly, some copyright scholars here and abroad question whether elaboration of a computer program constitutes "authorship" of the kind copyright should protect. 199 Moreover, despite their inclusion in the very first U.S. copyright statute, maps too have been the subject of controversy, with some U.S. courts recently suggesting that their factual nature precluded the presence of creative authorship. ${ }^{200}$ Authorship is a complex, expandable, and changeable concept ${ }^{201}$ whose articulation does not simply require "giving effect to a fairly absolute, enduring command rooted either in the words of the Constitution or in years of constitutional tradition."202 Rather, it is the

228-29 (3d ed. 1978) (emphatically distinguishing "industrial" sound recordings from "human, personal" works of authorship).

198. See, e.g., Copyright Statute, art. 2 (F.R.G.) (placing photographs in a category distinct from other works of authorship); Caroline Carreau, Mérite et Droit D'Auteur [Merit and Copyright] 359-412 (1981) (discussing difficulties French courts encountered applying special, more limitative, statutory criteria to copyright photographs); Desbois, supra note 197, at 81 (mechanical quality of photographs distinguishes them from other works of art); see also Berne Convention, supra note 7, art. 7.4 (permitting member countries to designate a shorter period of protection for photographs and works of industrial design).

199. See Sam Ricketson, People or Machines: The Berne Convention and the Changing Concept of Authorship, 16 Colum.-VLA J.L. \& Arts (forthcoming). See generally Association litteraire et artistique internationale, L'lnformatique et le Droit D'Auteur [Information and Copyright] (1990) (assembling reports from many countries on copyright protection of computer programs).

200. See, e.g., Kern River Gas Transmission Co. v. Coastal Corp., 899 F.2d 1458, 1463-64 (5th Cir.), cert. denied, 111 S. Ct. 374 (1990); Mason v. Montgomery Data Inc., 765 F. Supp. 353, 355-56 (S.D. Tex. 1991) (pre-Feist decision). But cf. David B. Wolf, Is There Any Copyright Protection for Maps After Fiest?, $39 \mathrm{~J}$. Copyright Soc'y 224, 238-42 (1992) (argning that creative elements of maps should be entitled to copyright protection after Feist).

201. See Copyright, Designs and Patents Act, 1988, ch. 48, arts. 3(1)(b), 9(3) (U.K.) (bringing computer-generated works within copyright, and identifying "authors" of these facially authorless works). On authorship and computer-generated works, see, e.g., Daniel Gervais, The Protection Under International Copyright Law of Works Created with or by Computers, 22 IIC 628 (1991); Pamela Samuelson, Allocating Ownership Rights in Computer-Generated Works, 47 U. Pitt. L. Rev. 1185 (1986).

202. Cox, supra note 175 , at 210 (describing situations in which stringent judicial review of constitutionality of congressional statutes is most appropriate).

By contrast, in considering the content of the constitutional terms "Writings" of "Authors," the Court has held that if the congressional interpretation at issue is of long standing, indeed if it was formulated roughly contemporaneously with the framing of the Constitution, then the interpretation is "entitled to very great weight, and ... [if sufficiently long standing] is almost conclusive." Burrow-Giles Lithographic Co. v. Sarony, 111 U.S. 53, 57 (1884) (regarding "[t]he construction placed upon the Constitution by the first [copyright] act of 1790, and the act of 1802"). There is strong historical evidence, which the Feist Court disregarded, permitting the conclusion that works that merely gather and report information are the "Writings" of "Authors": in 1790 , the first Congress designated as copyright subject matter, not only books, but maps and charts. See Act of May 31, 1790, ch. 15, 1 Stat. 124, reprinted in Copyright Enactments, supra note 193; Creation and Commercial Value, supra note 6, at 1876. Thus, copyright protection of facts was arguably within the Framers' intention, and 
kind of determination better made by a body both capable of gathering and investigating the facts that underlie assertions that a given production is the "Writing" of an "Author," and attuned as a result of those investigations to the economic and policy implications of inclusion or exclusion of the production from the ambit of copyright.

Let us apply these principles to the Feist problem. Assume Congress determines that production of informational databases of all kinds, including exhaustive compilations, furthers the progress of knowledge. Not only does this finding seem objectively true, it also falls squarely within the concept of the Patent-Copyright Clause. Next, Congress wishes to provide the means to promote the progress of knowledge by granting database compilers a limited monopoly in order to induce them to gather and disseminate information. The means are contemplated by the Constitution, as is the incentive rationale. ${ }^{203}$ Once Congress has made these determinations, what impediment to database copyright remains? The database must still be the writing of an author, one might rejoin, and Feist tells us that the database is not such a writing unless it is also original and minimally creative. But if Congress can determine what promotes knowledge, Congress should also be able to define the tools through which that progress is achieved.204 For example, suppose Congress enacted the "Database Copyright Protection Act of 1992," and in its preamble announced the following findings:

Congress has determined that informational databases constitute an important sector of economic and creative activity that promotes the progress of learning and access to information. Congress further finds that the grant of a limited monopoly on reproduction of compiled information (whether the information is in electronic or print form) is necessary to provide the incentive that database producers require to undertake the considerable effort and investment of gathering, compiling, and disseminating information. Congress similarly finds that without that incentive, the production of these works that contribute so importantly to the progress of knowledge would be

Congress' enactment today of a copyright statute that protects compilations of information would simply be giving effect to an authoritative interpretation. Cf. S. Rep. No. 315, supra note 180 , at 8 (relying on understanding contemporaneous with Framers' to justify Plant Patent Act's equation of "discovery" with "invention"). However, the argument from the Framers may be foreclosed after Feist; at least, the Court's rather ahistorical approach to copyright in information does not portend acceptance of this kind of argument in a later case.

203. See, e.g., Mazer v. Stein, 347 U.S. 201,219 (1954).

204. This is not to suggest there are no limits on Congress' definition of the Author and Writing terms. See, e.g., Hon. Pierre N. Leval \& Lewis Liman, Are Copyrights for Authors or Their Children?, 39 J. Copyright Soc'y 1, 4-11 (1991) (arguing that Court's interpretation of provision of Copyright Act designating statutory successors to renewal right vests copyright in persons other than the author or her assignee, and therefore is inconsistent with the Patent-Copyright Clause authorization to Congress to grant copyright "to Authors"). 
threatened. Finally, Congress finds that the acts of gathering and compiling information are not only useful, but creative; that considerable intellectual labor is necessary to assemble a compilation, and even to determine what kinds of information compilations, including exhaustive directories, are useful and desirable. Congress therefore finds that persons who independently compile information are "Authors," and their productions are "Writings" within the meaning of the Constitution.

Given such extensive and specific congressional consideration of the issue, it is surely arguable that the Supreme Court, ruling on the constitutionality of the Database Copyright Protection Act of 1992, should defer to Congress' findings of fact and their stated relationship to the constitutional purpose for Congress' authority. ${ }^{205}$ For even if Feist articulates a more stringent characterization of the scope of Congress' copyright power, the Court did not there confront a statute that clearly purported to protect unoriginal compiled information. On the contrary, the Court first found that the current Copyright Act itself excluded the compilation at issue. ${ }^{206}$

This Article's examination of the implications of the Court's constitutional analysis has revealed impediments to enacting an appropriate information protection statute under alternate sources of congressional power, as well as the problematic nature of the Court's approach to the Patent-Copyright power. These observations should illustrate the dangers of premature constitutional adjudication of Congress' copyright power. Indeed, it is ironic that the Feist opinion's author, while announcing an unsought constitutional resolution here, elsewhere last Term admonished the Court for unnecessary decisions of constitutional issues. ${ }^{207}$ Were Congress to enact legislation like the statute posited here, the Court should perceive this action not as a provoca-

205. Tax law affords an analogy. In Eisner v. Macomber, 252 U.S. 189, 219 (1920), the Court held that dividends paid out in shares of a company's stock (as opposed to cash dividends) were not "income" within the meaning of the Sixteenth Amendment. Because the Sixteenth Amendment provides the only exception to the Constitution's requirement that direct taxes be apportioned according to the population of the states, see id. at 205-06, the Court further held that Congress had no power to tax dividends paid in stock. See id. at 219. Although section 305(a) of the Internal Revenue Code has codified the Macomber principle, section 305 (b) nonetheless taxes a wide variety of dividends paid in the form of stock. Compare 26 U.S.C. $\$ 305$ (a) (1988) with id. $\$ 305$ (b). Professor Andrews has rhetorically questioned Macomber: "Doesn't the power to tax income necessarily include the power, within limits, to define it?" William D. Andrews, Basic Federal Income Taxation 255-56 (4th ed. 1991).

206. See Feist Publications, Inc. v. Rural Tel. Serv. Co., 111 S, Ct. 1282, 1297 (1991). Having found that the statute barred plaintiff's claim, the Court had no further need to declare a constitutional basis for the result, much less announce that basis "no fewer than thirteen times," Goldstein, supra note 4, at 119.

207. See Rust v. Sullivan, 111 S. Ct. 1759, 1788-89 (1991) (O'Connor, J., dissenting); see also Webster v. Reproductive Health Servs., 109 S. Ct. 3040, 3060-61 (1989) (O'Connor, J., concurring in part and concurring in the judgment) ("Where 
tion, but as an invitation to reconsider some of Feist's grander pronouncements.

If Congress does have power to grant copyright protection to compiled information, even when the compilation fails the Feist standard of creative originality, a fortiori, Congress has power to grant anticopying protection under the Commerce Clause as well, for there is no longer a conflict between the two grants of authority. Does it matter which clause Congress selects?208 Legislation under the Commerce Clause presents some advantages. Assuming the Commerce Clause-based legislation followed a compensation rather than a control model of reproduction rights, the legislation would be characterized by compulsory licenses or by voluntary collective licenses. ${ }^{209}$ Even if such licenses do not conflict with the Patent-Copyright Clause principle of "exclusive Right," 210 compulsory licenses are nonetheless a disfavored mechanism in copyright law. ${ }^{211}$ It might therefore be preferable to avoid freighting the copyright scheme with a regime that relies heavily on compulsory licenses. On the other hand, legislation under the PatentCopyright Clause would enable Congress to retain the copyright label of protection, even under an essentially sui generis regime.

Considerations of international protection suggest Congress should opt for extra-copyright protection of the "sweat" component of compilations. The recently disclosed European Communities (EC) Commission Proposal for a Council Directive on the Legal Protection of Databases ${ }^{212}$ combines copyright and sui generis approaches. The EC Commission's proposal would confirm copyright protection for databases that are "original" in their selection or arrangement of mate-

there is no need to decide a constitutional question, it is a venerable principle of this Court's adjudicatory processes not to do so .....").

208. Both the Semiconductor Chip Protection Act, 17 U.S.C. $\$ \S 901-914$ (1988) and the Plant Variety Protection Act, 7 U.S.C. $\$ \S 2321-2583$ (1988) were enacted pursuant to the Commerce Clause and the Patent-Copyright Clause. See supra note 146.

209. Voluntary collective licenses and compulsory licenses share many characteristics. In both cases, copyright owners make their works available to users on a nondiscriminatory basis. In effect, the copyright owner exchanges the right to refuse to authorize the user, or to pick and choose among users, in exchange for compensation. A compulsory license requires the copyright owner to engage in this exchange, and a government agency sets the rate of compensation and administers the pay-out. In voluntary collective licensing, copyright owners privately agree to make their repertory available, and set their own rates (subject to antitrust constraints). See, e.g., Creation and Commercial Value, supra note 6 , at 1932-34, and sources cited therein.

210. See supra notes $162-164,166$ and accompanying text.

211. See, e.g., Goldstein, supra note 86, at 1135-36; cf. Goldstein, supra note 4, at 119 (" $[w]$ ithin such a new statutory framework [protecting databases under the commerce clause], all copyright bets will be off: ... a different remedial array, possibly including compulsory licensing, may be offered").

212. Adopted Jan. 29, 1992 [hereinafter Proposed Directive]. The draft directive concerns only electronic compilations. See id. art. 1.1. 
rial. ${ }^{213}$ However, recognizing that some databases, particularly exhaustive ones, may lack originality, and further acknowledging that even as to original electronic compilations, greatest value may lie in the uncopyrightable factual content, the draft directive proposes a special right to prevent "unfair extraction of the contents" of databases, whether the database as a whole is original or not."14 The "unfair extraction" claim closely resembles a "sweat" right: the right would prevent "unauthorized extraction and reutilization of the contents" so long as these can be "independently created, collected or obtained from any other source;" if they cannot, the database producer must license second-comers. ${ }^{215}$ The proposed "unfair extraction" right manifests other important differences from copyright: it endures for only ten years after the database is publicly available; ${ }^{216}$ and foreign databases will be protected not on the basis of the copyright rule of national treatment, ${ }^{217}$ but on the basis of reciprocity. ${ }^{218}$ For American databases that do not benefit under the terms of the draft directive, ${ }^{219}$ it appears that no protection in the EC would be availiable unless the EC Council determines that the United States affords equivalent protection to EC databases. Because the EC Commission has vividly distingnished the "unfair extraction" right from copyright, American protection under the "copyright" rubric might not be deemed to meet the EC standard.

\section{First Amendment Implications of a Statute Protecting Compiled Information}

Even if Congress has authority under the Patent-Copyright Clause or under the Commerce Clause to legislate some form of anticopying protection for compiled information, would such legislation be consistent with the First Amendment? Most authorities agree that traditional copyright protection does not clash with the First Amendment because copyright protects the "expression" of information, rather than the information itself. ${ }^{220}$ As a result, public access to the "facts" recounted

213. See id. art. 2.3.

214. See id. arts. 2.5, 8; Explanatory Memorandum, art. 3.2.7-8.

215. Id. art. 8.1.

216. See id. art 9.3; cf. supra note 161 and sources cited therein (discussing 10-year period of protection for unoriginal works in Nordic countries).

217. See Berne Convention, supra note 7, at art. 5.I.

218. See Proposed Directive, Preamble, § 38; art. 11.3.

219. Article 11 of the draft directive sets forth the beneficiaries of the "unfair extraction" right. These include foreign database producers who have a "registered office on the territory of the Community," and whose "operations . . . possess an effective and continuous link with the economy of one of the Member States." Id. art. 11.2 .

220. See 17 U.S.C. $\S 102$ (1988) (codification of "idea/expression dichotomy"); see, e.g., Robert C. Denicola, Copyright and Free Speech: Constitutional Limitations on the Protection of Expression, 67 Cal. L. Rev. 283, 289-93 (1979); Paul Goldstein, Copyright and the First Amendment, 70 Colum. L. Rev. 983, 1016-20 (1970); Melville 
in copyrighted works remains, in theory, unimpeded. ${ }^{221}$ The statute here proposed, however, would protect the information as such. Is a First Amendment conflict therefore ineluctable?

While extended discussion of the relationship between copyright and the First Amendment is beyond the scope of this Article, ${ }^{222}$ two general considerations suggest that proprietary interests in information can be supported without undue incursion on speech interests in information. The first concerns the overall relationship of the PatentCopyright Clause and the First Amendment. The second concerns the proposed scope of statutory protection of compiled information.

First, the question arises whether copyright should be viewed as constituting a limited exception to the First Amendment, or whether copyright protection is consistent with the First Amendment. Were copyright an exception to the First Amendment, then arguably, no proprietary rights in information could coexist with the First Amendment outside the copyright (and patent) scheme. As a result, informational subject matter outside the scope of copyright could not be protected against copying. Moreover, Congress' ability to define the subject matter and scope of copyright to cover the copying of information would be significantly circumscribed. But the Supreme Court has continued since International News Service v. Associated Press to uphold state and federal anticopying protection of uncopyrighted subject matter, including information. ${ }^{223}$ If copyright does not constitute the only permissible source of information protection, then its coverage of information need not be tightly limited.

Once the categorical objection is removed, the inquiry focuses on the balance between the governmental interest in preventing the copying of compiled information and First Amendment concerns. We have already considered several aspects of the governmental, and the public, interest in protection. Arguably, the information compilation's lack of creative originality makes the federal interest in protecting the work

B. Nimmer, Does Copyright Abridge the First Amendment Guarantees of Free Speech and Press?, 17 UCLA L. Rev. 1180, 1189-93 (1970).

221. See also Jon O. Newman, Copyright Law and the Protection of Privacy, 12 Colum.-VLA J.L. \& Arts 459, 469, 478-79 (1988) (arguing that personal reflections contained in private writings should be afforded widest degree of protection under copyright).

222. See articles cited supra note 220; see also Tiffany D. Trunko, Note, Remedies for Copyright Infringement: Respecting the First Amendment, 89 Colum. L. Rev. 1940 passim (1989) (arguing that in some cases reconciling copyright protection with First Amendment values will require courts to "decouple" analysis of liability and remedy in infringement cases).

223. See, e.g., Carpenter v. United States, 484 U.S. 19, 27-28 (1987) (federal common law protection of confidential information); Zacchini v. Scripps-Howard Broadcasting Co., 433 U.S. 562 (1977) (rejecting First Amendment challenge to state right-of-publicity protection of performing artist's act); Goldstein v. California, 523 U.S. 546 (1974) (rejecting preemption challenge to state record antipiracy laws, when Congress had not yet brought sound recordings within the subject matter of copyright). 
different or lesser than when an expressive work is at issue. Nonetheless, the interest is not only present, but can be reconciled with First Amendment principles. A compiled information protection statute and the First Amendment share certain goals. Both seek to promote the progress of knowledge: the compilation legislation through incentives to information gathering; the First Amendment through the principle of the public interest in access to information. As the Supreme Court observed in a copyright decision, copyright and First Amendment interests are not antagonistic; rather the copyright monopoly is "the engine of free expression."224 Moreover, the incentive and access principles must be kept in balance; were access to overbear, the resulting diminution of incentives might lead to the production of fewer works to which to gain access. ${ }^{225}$ Admittedly, the Supreme Court's pronouncements concerned "expression" rather than "facts," but the argument seems equally applicable to production of works of information.

If information protection promotes an important governmental interest that is not inevitably inimical to the First Amendment, the second, and more important, question is how the statute could be drafted to attenuate First Amendment objections. ${ }^{226}$ Protection might be granted only against for-profit commercial copying of compiled information whose purpose is to produce another compilation. Imposing liability only on other compilers addresses the main economic actors, and seems necessary to avoid a "chilling effect" on authors of factual narratives. Arguably, only other compilers are likely to appropriate economically significant amounts of information from a given compilation; the impact on an information gatherer should a historian consult a compilation to cull facts regarding, for example, weather patterns in the Midwest in 1989, seems minimal. By contrast, the historian's researches, and eventual contributions to the progress of knowledge, could be significantly encumbered or discouraged were she obliged to account for, and pay compilers for, these disparate and rather slim uses of information. ${ }^{227}$

Another method of tailoring a compiled information statute to further First Amendment interests would qualify the compiler's exclusive rights by imposition of compulsory licenses. ${ }^{228}$ This device ensures

224. Harper \& Row Publishers Co. v. Nation Enters., 471 U.S. 539, 558 (1985).

225. See id. at 558-59.

226. Cf. City of Renton v. Playtime Theaters, lnc., 475 U.S. 41, 47-50 (1986) (content-based restrictions presumptively violate First Amendment; time, place, and manner restrictions should be analyzed to determine whether they "serve a substantial governmental interest and allow[] for reasonable alternative avenues of communication"); Clark v. Community for Creative Non-Violence, 468 U.S. 288, 293 (1984) (same).

227. Cf. Jessica Litman, supra note 38, at 1014-16 (distinguishing factual narratives from compilations).

228. See generally Creation and Commercial Value, supra note 6, at 1924-36 (proposing compulsory collective licensing of derivative information compilations). 
other compilers access to the information, albeit for a fee. Once access is available, however, the First Amendment does not necessarily command that it be gratis. ${ }^{229}$ A more significant objection to compulsory licensing would contend that this device puts the government in the unseemly and dangerous position of licensing access to information. But so long as the licenses were equally available to all applicants, the government could not pick and choose licensees. ${ }^{230}$ Moreover, were compilation reproduction rights administered by nondiscriminatory voluntary collective licensing, ${ }^{231}$ the specter of government censorship would be largely dispelled.

Finally, a compiled-information statute might promote First Amendment interests by offering compilers an incentive to disseminate. In the current post-Feist uncertainty, an information compiler may be leery of releasing her data in any easily copied format. Fearing an absence of legal protection, she may turn to a variety of devices, contractual and technological, to restrict access to the data. The proposed statute should afford the missing assurance of meaningful protection, and therefore may enhance access to compiled information.

\section{ConcLusion}

In Feist, the Supreme Court rejected the "sweat of the brow" basis for copyright protection, stressing instead a constitutional standard of creative originality and a constitutional principle of free riding on uncreative efforts. The Court thereby sought to promote wide and cheap public access to information. Ironically, the elimination of "sweat" copyright may require information providers to restrict access to compilations in order to maintain a contractual or technological hold on the material. ${ }^{232}$ Similarly, the costs of "added value" of subjective elements to make the compilation copyrightable as a whole will be passed along to consumers, many or most of whom may not have wished these features in the first place. As a result, Feist may make access to informa-

229. Cf. Zacchini v. Scripps-Howard Broadcasting Co., 433 U.S. 562, 578 (1977) (upholding against First Amendment challenge a state right-of-publicity law under which plaintiff claimed payment for unauthorized broadcast of his "human cannonball" act).

230. Cf. 17 U.S.C. $\S \S 115-19$ (1988) (variety of compulsory licenses already within the Copyright Act).

231. Cf. id. § $116 \mathrm{~A}$ (voluntary collective license for performance of musical compositions on jukeboxes). ASCAP, the music performing rights licensing collective, is an example of nondiscriminatory voluntary collective licensing. See generally Bernard Korman \& 1. Fred Koenigsberg, Performing Rights in Music and Performing Rights Societies, $33 \mathrm{~J}$. Copyright Soc'y 332, 348-67 (1986) (arguing that performance rights societies are necessary to fulfill purpose of copyright).

232. See Creation and Commercial Value, supra note 6, at 1921-22 ("Privatizing information through contract, encryption, and similar devices may carry greater individual and social costs than would a copyright system. . . [C]onsumer access to information may be more expensive without copyright than with it."). 
tion both more burdensome and more expensive than had copyright protection been available.

This observation heightens the desirability of an alternative form of protection. State misappropriation law, however, is probably preempted, and, in any event, is not the ideal solution. A carefully tailored federal anticopying statute that would incorporate some form of compulsory or voluntary collective licensing may supply a more satisfactory response. However, the Supreme Court's repeated insistence in Feist that the creative originality standard is "constitutionally mandated" gives rise to constitutional questions concerning Congress' authority to regulate subject matter that the Supreme Court has declared beyond Congress' power to protect under the Patent-Copyright Clause.

This Article has argued that Congress retains power under the Commerce Clause to enact an anticopying statute that departs in significant ways from the traditional copyright scheme. It has also contended that Feist notwithstanding, Congress does have power under the PatentCopyright Clause to protect compiled information. It is for Congress to judge what works "promote the Progress of Science," and its determination of what "Writings" of "Authors" fulfill that goal should receive considerable judicial deference. Finally, whatever the Article I, Section 8 source of authority for the legislation, a federal misappropriation statute could survive First Amendment scrutiny were the protection limited to claims against commercial copying by other compilers, and were access to the information assured through compulsory or voluntary collective licensing. 